DUCE, Mauricio; VILLARROEL, Romina, "Indemnización por error judicial: una aproximación empírica a la jurisprudencia de la Corte Suprema de los años 2006-2017” Polít. Crim. Vol. 14, No 28 (Diciembre 2019), Art. 6, pp. 216-268. [http://politcrim.com/wp-content/uploads/2019/12/Vol14N28A6.pdf]

\title{
Indemnización por error judicial: una aproximación empírica a la jurisprudencia de la Corte Suprema de los años 2006-2017
}

\section{Compensation for miscarriages of justice: an empirical approach to the Supreme Court decisions years 2006-2017}

\author{
Mauricio Duce J. \\ Abogado, Magíster en Ciencias Jurídicas Profesor (J.S.M) Universidad de Stanford, \\ Profesor Titular Facultad de Derecho Universidad Diego Portales. \\ mauricio.duce@udp.cl \\ Romina Villarroel V. \\ Licenciada en Ciencias Jurídicas y Sociales y Magíster en Derecho Penal y Procesal Penal \\ Facultad de Derecho Universidad Diego Portales \\ romina.villarroel@mail.udp.cl
}

Resumen: El objetivo del trabajo es contribuir al mejor conocimiento del mecanismo de indemnización por error judicial contemplado en el artículo $19 \mathrm{n}^{\circ} 7$ letra i) de la Constitución, por medio de un estudio de corte empírico del total de solicitudes presentadas a la Corte Suprema en el período comprendido entre los años 2006 a 2017. Se pretende determinar si, en la práctica, el funcionamiento de esta herramienta entrega una adecuada protección y cobertura para reparar a las personas que han sido objeto de condenas e imputaciones erróneas. El trabajo concluye que esta institución está todavía lejos de cumplir adecuadamente con las necesidades de reparación de las víctimas de los errores, tanto por problemas de regulación normativa, pero especialmente de los derivados de la interpretación y aplicación de los criterios señalados en la Constitución. Además, se identifican potenciales problemas de acceso y calidad del litigio de los solicitantes para lograr este objetivo.

Palabras clave: Indemnización por error judicial; errores judiciales; estudios empíricos.

Abstract: The paper's objective is to contribute to the better understanding of the mechanism of compensation for miscarriages of justice regulated un article $19 \mathrm{n}^{\circ} 7 \mathrm{i}$ ) of the Constitution by an empirical study from the total amount of petitions before the Supreme Court between years 2006-2017. The goal is to establish if the current practice gives adequate coverage and protection to the people that has been victim of wrongful convictions or wrongful prosecutions. The work concludes that this institution is still far from fulfill the compensation needs of the victims of such mistakes. The problems are at the level of normative regulation, but especially derives from the interpretation and use of the criteria contained in the Constitution. In addition, there are also some potential problems related to the access of this tool and quality of litigants that present the petitions.

\footnotetext{
* Trabajo realizado en el contexto de preparación y ejecución del proyecto Fondecyt regular n ${ }^{\circ} 1190016$ "Mecanismos de corrección y reparación de condenas e imputaciones erróneas: un análisis dogmático, empírico y comparado." Investigador responsable: Mauricio Duce.
} 


\section{Polít. Crim. Vol. 14, No 28 (Diciembre 2019), Art. 6, pp. 216-268. [http://politcrim.com/wp-content/uploads/2019/12/Vol14N28A6.pdf]}

Key words: compensation for miscarriages of justice; wrongful convictions; empirical studies.

\section{Introducción}

Todos los sistemas de justicia criminal en el mundo están expuestos a la posibilidad de cometer errores. Dentro de ellos, nos preocupan especialmente dos tipos para efectos de este trabajo. En primer lugar, aquellos que se traducen en la condena de una persona inocente (que identificaremos como "condenas erróneas"). Luego, aquellos que se producen cuando se adoptan decisiones equivocadas en etapas previas al juicio sin llegar a una sentencia definitiva, por ejemplo, casos que han tenido una prisión preventiva extendida y que posteriormente son objeto de sobreseimiento o absolución del imputado basado en un aspecto que pudo haberse detectado mucho antes si se hubiera actuado con diligencia (los que llamaremos "imputaciones erróneas").

Como ha dicho la doctrina, si bien los problemas detrás de estos dos tipos de errores son diferentes, los factores que los generan son muy similares y, especialmente, sus efectos resultan igualmente devastadores. ${ }^{1}$ En esta dirección, la evidencia comparada indica que ellos producen enormes daños psicológicos, económicos, familiares y sociales para quienes los sufren, especialmente derivados de las privaciones de libertad a que normalmente son sometidas las víctimas de los mismos. ${ }^{2}$ Casos anecdóticos documentados en nuestro país apuntan en el mismo sentido. ${ }^{3}$

En este contexto, la evidencia comparada muestra que los sistemas de justicia penal se equivocan con una frecuencia superior a lo que habitualmente creemos. Así se desprende de las investigaciones que han establecido una tasa potencial de condena de inocentes en ciertas categorías de delitos ${ }^{4}$ o a través de registro sistemático de casos de exoneraciones en donde se ha acreditado la inocencia del condenado. ${ }^{5}$ Además, también sabemos que una

${ }^{1}$ FORST, Brian, Wrongful Conviction and Miscarriages of Justice, Causes and Remedies in North American and European Criminal Justice Systems: Wrongful Convictions in a World of Miscarriages of Justice, New York: Routledge, 2013, p. 17

2 CAMPBELL, Katryn, DENOV, Myriam, "The burden of innocence: coping with a wrongful imprisonment", Canadian Journal of Criminal Law and Criminal Justice, $\mathrm{n}^{\circ} 46$ (2004), pp. 139-163, passim; GROUNDS, Adrian, "Psychological consequences of wrongful convictions and imprisonment", Canadian Journal of Criminal Law and Criminal Justice, $\mathrm{n}^{\circ} 46$ (2004), pp. 165-182, passim; SCOTT, Leslie, "It never ends: the psychological impact of wrongful convictions", American University Criminal Law Brief, vol. 5, $\mathrm{n}^{\circ}$ 2 (2010), art. 2, pp. 9-22, passim.

${ }^{3}$ El Proyecto Inocentes de la Defensoría Penal Pública ha documentado, a diciembre de 2018, 62 casos de imputaciones erróneas y dos de condenas erróneas mostrando los enormes perjuicios causados a sus víctimas. Especialmente recomendamos revisar la sección de videos con varios testimonios de las víctimas de estos errores hablando sobre el impacto que ellos tuvieron o siguen teniendo en sus vidas. Véase http://www.proyectoinocentes.cl/sala_prensa/videos/page/3 [Visitado el 18.1.2019]

${ }^{4}$ RISINGER, Michael "Innocent convicted: an empirically justified wrongful conviction rate", The Journal of Criminal Law and Criminology, vol. 97, $\mathrm{n}^{\circ} 3$ (2007), pp. 761-806, passim; GROSS, Samuel, et al, "Rate of false convictions of criminal defendants who are sentenced to death", Proceedings of the National Academy of Sciences of the United States of America, vol. 11, $\mathrm{n}^{\circ} 20$ (2014), pp.7230-7235, passim.

5 Por ejemplo, en los Estados Unidos en instituciones como el Innocence Project (https://www.innocenceproject.org/) y el National Registry of Exonerations 
gran cantidad de los errores se producen como consecuencia de malas prácticas del propio sistema, por ejemplo, en materia de reconocimientos oculares, uso de prueba pericial, valoración de confesiones, uso de testigos poco confiables, mal comportamiento de las agencias de persecución penal, entre otros. ${ }^{6}$

En el caso de Chile, evidencia reciente nos muestra la existencia de una cantidad importante de casos de condenas erróneas que era desconocida hasta hace poco. En efecto, un estudio ha identificado 48 recursos de revisión acogidos por la Corte Suprema de casos del sistema acusatorio sólo en el período $2007-2016 .^{7}$ Hay también evidencia creciente acerca de la existencia de casos de imputaciones erróneas. ${ }^{8}$ Por su parte, otras investigaciones muestran la presencia de diversos comportamientos de actores del sistema que nos exponen a ambos tipos de errores. Así, la evidencia identifica y describe prácticas muy similares a las descritas por la investigación comparada como aquéllas que tienen más incidencia en explicar los errores del sistema en áreas como: la realización de reconocimientos oculares ${ }^{9}$ y el uso de la prueba pericial ${ }^{10}$, entre otros.

En consecuencia, hoy sabemos que errores con graves consecuencias para las víctimas de los mismos no son ajenos a nuestra realidad. En este escenario una pregunta obvia es ¿Qué hace nuestro país para reparar estos errores?

La respuesta tradicional que nuestro sistema jurídico ha entregado a esta pregunta es el mecanismo conocido como la acción de indemnización por error judicial previsto en el artículo $19 \mathrm{n}^{\circ} 7$ letra i) de la Constitución, el que -al menos en teoría- permitiría indemnizar a personas que han sufrido daños como consecuencia de condenas e imputaciones erróneas. ${ }^{11} \mathrm{Si}$ bien dicha institución ha sido objeto de análisis doctrinario importante

(http://www.law.umich.edu/special/exoneration/Pages/about.aspx) o en Inglaterra, Gales e Irlanda del Norte por el trabajo de la Criminal Case Review Commission (https://ccrc.gov.uk/).

${ }^{6}$ GARRET, Brandon, Convicting the Innocent: Where Criminal Prosecutions Go Wrong, Estados Unidos: Harvard University Press, 2011; SIMON, Dan, In Doubt: The Psychology of the Criminal Justice Process, Estados Unidos: Harvard University Press, 2012; GOULD, Jon, et al, "Predicting Erroneous Convictions", Iowa Law Review, vol. 99, 2014, pp. 471-522.

${ }^{7}$ En todos ellos la Corte Suprema estableció que había existido una condena errada de una persona inocente. DUCE, Mauricio, "Los recursos de revisión y la condena de inocentes en Chile: una aproximación empírica en el periodo 2007-2016", en Doctrina y jurisprudencia penal: Recursos de amparo y revisión, n³0 (2017), pp. 3-40.

8 Nuevamente recomendamos revisar la página del Proyecto Inocentes de la Defensoría Penal Pública la que, a diciembre de 2018, tenía documentado 62 casos con este tipo de errores (http://www.proyectoinocentes.cl/).

9 DUCE, Mauricio, "Los reconocimientos oculares: una aproximación empírica a su funcionamiento y algunas recomendaciones para su mejora", Polít. crim. Vol. 12, $\mathrm{N}^{\circ} 23$ (2017), Art. 9, pp. 291-379; CASTILLO, Ignacio, "Enjuiciando al Proceso Penal Chileno desde el Inocentrismo (algunos apuntes sobre la necesidad de tomarse en serio a los inocentes)", Revista Política Criminal, Vol. 8, no 15 (2013), pp. 249-313.

${ }^{10}$ DUCE, Mauricio, "Una aproximación empírica al uso y prácticas de la prueba pericial en el proceso penal Chileno a la luz de su impacto en los errores del sistema", Polít. crim. Vol. 13, No 25 (2018), Art. 2, pp. 42103; DIRECCIÓN DE ESTUDIOS DE LA CORTE SUPREMA, Peritajes en Chile, Santiago: Corte Suprema, 2017, 47 pp.; GONZÁLEZ-WILHELM, Leonardo, Prueba pericial, litigación con peritos y medicina legal, Santiago: Thomson Reuters, 2018.

${ }^{11}$ La Ley n 19.640 de 15 de octubre de 1999 que estableció la Ley Orgánica Constitucional del Ministerio Público incorporó en su artículo $5^{\circ}$ una regla de responsabilidad civil por "Conductas injustificadamente erróneas o arbitrarias del Ministerio Público", ampliando de esta forma la posibilidad de obtener reparación 


\section{Polít. Crim. Vol. 14, No 28 (Diciembre 2019), Art. 6, pp. 216-268. [http://politcrim.com/wp-content/uploads/2019/12/Vol14N28A6.pdf]}

durante su vigencia, no existe a la fecha una investigación de corte empírico sistemático que permita comprender con mayor precisión el comportamiento de nuestra Corte Suprema al pronunciarse frente a los requerimientos presentados en esta materia y, por esta vía, conocer el funcionamiento práctico de esta institución más allá de la regulación contenida en los textos normativos en los que se sustenta. Muchos de los textos de la doctrina hacen referencia a algunos casos o hacen un seguimiento de parte de la jurisprudencia, pero no muestran un cuadro completo ni sistemático actualizado sobre la materia. ${ }^{12}$ En este contexto, el objetivo de este trabajo es contribuir al conocimiento de esta institución por medio de un estudio de corte empírico del total de solicitudes de indemnización por error judicial presentadas a la Corte Suprema en el período comprendido entre los años 2006 a 2017. Se intentará por esta vía determinar si el funcionamiento en la práctica este mecanismo entrega adecuada protección y cobertura para reparar a las personas que han sido objeto de ambos tipos de errores que hemos identificado.

Para cumplir con los objetivos propuestos, este trabajo se divide en cinco secciones además de esta introducción y las conclusiones finales. En la primera de ellas se realizará una muy breve revisión de cuestiones generales sobre el mecanismo, así como algunos datos disponibles sobre su utilización desde su establecimiento en la constitución de 1980 hasta marzo del año 2018. Debemos señalar que no se trata de una investigación dogmática sobre la materia, por lo que no esperamos revisar en detalle la configuración legal de esta institución que, como ya hemos dicho, ya ha sido objeto de análisis por la doctrina nacional. La segunda, estará destinada a realizar una descripción del universo de casos estudiados, así como una caracterización general de los mismos. La tercera sección se detiene en el análisis de los casos declarados inadmisibles por la Corte Suprema, tanto en la forma como en el fondo. En la cuarta nos dedicamos al análisis de los casos en que la Corte Suprema rechaza la solicitud por razones de fondo, poniendo especial énfasis en la interpretación que la Corte ha dado a la exigencia que se traten de errores basados en resoluciones "injustificadamente erróneas o arbitrarias". Finalmente, en la quinta sección se describen brevemente los casos acogidos en el período y se hace un análisis de los mismos. Luego de las conclusiones se incluye un anexo con el listado completo de los casos que fueron objeto de análisis en la investigación

\footnotetext{
por errores causados por el comportamiento de fiscales. Si bien la fórmula utilizada por nuestro legislador se inspira en el lenguaje de la Constitución para la indemnización por error judicial, se trata de un estatuto de responsabilidad separado que no es objeto de estudio en este trabajo. Información empírica reciente proporcionada por el Consejo de Defensa del Estado indica que entre el año 2005 y octubre de 2018 se habían presentado 147 demandas utilizando esta regla, de las cuáles seis habrían sido acogidas (dos de ellas con sentencias no ejecutoriadas a esa fecha). Véase Oficio Ordinario n ${ }^{\circ} 004084$ de 9 de noviembre de 2018. Agradecemos a la periodista de El Mercurio Andrea Chaparro quien nos hizo entrega de esta información que consiguió para efectos de un artículo que publicó en el mismo diario el 27 de noviembre de 2018.

${ }^{12}$ Una parte importante de esta literatura será citada en las próximas secciones del trabajo. El trabajo que probablemente analiza en forma más sistemática la jurisprudencia existente a esa fecha, el año 2004, es el de CARMONA, Carlos, "La responsabilidad del Estado-juez: Revisión y proyecciones", Revista de Derecho Público, vol. 66 (2004), pp. 307-357, passim. La jurisprudencia hasta el año 1985 se puede ver en CALDERA, Hugo, "Interpretación que la Corte Suprema ha dado a la norma constitucional sobre indemnización del error judicial”, Revista de Derecho Público, n³7-38 (1985), pp. 335-364, passim.
} 
DUCE, Mauricio; VILLARROEL, Romina, "Indemnización por error judicial: una aproximación empírica a la jurisprudencia de la Corte Suprema de los años 2006-2017”

\section{Algunos aspectos generales sobre la indemnización por error judicial en Chile y su uso}

La indemnización por error judicial se introdujo por primera vez en nuestro ordenamiento constitucional en el texto del año 1925 (artículo 20) estableciendo una cláusula indemnizatoria bastante generosa ${ }^{13}$, pero que sin embargo no tuvo vida operativa por falta de dictación de la ley que implementara la posibilidad de ejercerla, tal como exigía el propio precepto constitucional. ${ }^{14}$ Este "problema regulatorio" fue corregido en la Constitución de 1980 al establecerse una cláusula "autosuficiente", es decir, que no requería de la dictación de una ley para su puesta en marcha. ${ }^{15}$ Con todo, al momento de definir el texto final, el constituyente manifestó especial preocupación a que una cláusula que estableciera una posibilidad muy amplia de acceder a indemnización como la de la Constitución de 1925 pudiera generar efectos negativos, ya sea por los costos que podría significar al erario público ${ }^{16}$ o por un potencial efecto de incentivar comportamientos defensivos de los jueces en la investigación de los delitos (recordemos que estaba en vigencia sistema inquisitivo a la fecha y que el rol de investigación estaba en manos de los jueces del crimen). ${ }^{17}$

A la luz de estas preocupaciones, el constituyente de 1980 estableció varias restricciones a la cláusula del artículo $19 \mathrm{n}^{\circ} 7$ letra i). Por de pronto, es necesario recordar que lo que permite esta acción de indemnización por error judicial es la obtención de una autorización o declaración previa por parte de la Corte Suprema que, en caso de ser acogida, habilita luego la presentación de la demanda de indemnización en sede civil. En ese contexto las dos principales limitaciones que se regularon se vinculan a delimitar los casos que pueden ser considerados para efectos de esta autorización o declaración previa. De acuerdo a la primera de ellas, sólo puede ser titular de esta acción una persona que hubiera sido "sometida a proceso" o "condenada". En ambas hipótesis la regla establece que dicha persona tiene luego haber sido absuelta o sobreseída definitivamente en cualquier instancia. Además, se establece una exigencia adicional a la decisión judicial que sometió a proceso o

\footnotetext{
${ }^{13} \mathrm{El}$ texto de dicho artículo señalaba "Todo individuo a favor de quien se dictare una sentencia absolutoria o se sobreseyere definitivamente, tendrá derecho a indemnización, en la forma que determine la ley, por los perjuicios efectivos o meramente morales que hubiere sufrido injustamente". Como se puede apreciar, esta norma operaba sobre la base de una suerte de estatuto de responsabilidad objetivo, bastando la existencia de una absolución o de un sobreseimiento para tener derecho a una indemnización.

${ }^{14}$ CARMONA, "La responsabilidad del Estado-juez", cit. nota nº12, p. 311; EVANS, Enrique, Los derechos constitucionales, t. II, Santiago: Editorial Jurídica de Chile, 1986, p. 88; DÍAZ, Nataly; MUÑOZ, Pamela, "La responsabilidad del Estado-Juez: Buenas razones para proponer una acepción amplia de error judicial en Chile”, Revista de Derecho Público, vol. 83, 2 semestre (2015), pp. 37-60, p. 39.

${ }^{15}$ Esto sin perjuicio de la regulación de un autoacordado de 1996 (que reemplazó a uno previo de 1983) que complementa la regulación constitucional. Véase Autoacordado de la Corte Suprema de 24 de mayo de 1996 "Que reglamenta el procedimiento para obtener la declaración previa al ejercicio de la indemnización que concede la letra i) del número 7 del artículo 19 de la Constitución Política de la República".

${ }^{16}$ CALDERA, "Interpretación", cit. nota nº12, p. 348; CARMONA, "La responsabilidad del Estado-juez", cit. nota ${ }^{\circ} 12$, p. 311; EVANS, Los derechos, cit. nota $\mathrm{n}^{\circ} 14$, p. 114.

${ }^{17}$ BARROS, Enrique, Tratado de responsabilidad extracontractual, Santiago: Editorial Jurídica de Chile, 2006, p. 525; GARRIDO, Mario, "La Indemnización por Error Judicial en Chile", Revista Ius et Praxis, año $5, \mathrm{n}^{\mathrm{o}} 1$ (1999), pp. 473-482, p. 478.
} 


\section{Polít. Crim. Vol. 14, No 28 (Diciembre 2019), Art. 6, pp. 216-268. [http://politcrim.com/wp-content/uploads/2019/12/Vol14N28A6.pdf]}

condenó, ya que sólo sería procedente demandar civilmente tratándose de resoluciones que la propia Corte Suprema califique como "injustificadamente erróneas o arbitrarias".

Esta regulación habría producido el efecto de restringir la procedencia de este mecanismo. De hecho, hasta hace poco la doctrina había sostenido que sólo en cuatro casos la Corte habría dado lugar a la solicitud. ${ }^{18}$ Esto se explicaría centralmente como consecuencia de las propias exigencias constitucionales y de la interpretación estricta que de ellas habría tenido la Corte Suprema, tema en el que no pareciera haber discrepancia en la doctrina nacional, especialmente tratándose del alcance que se le ha dado a las expresiones "injustificadamente errónea o arbitraria." 1920

${ }^{18}$ BALLIVIAN, Pedro, "Responsabilidad del Estado por conductas injustificadamente erróneas o arbitrarias del Ministerio Público: análisis comparativo y jurisprudencial", Revista Ius et Praxis, Año 19, № 2 (2013), pp. 53-84, p. 54; CARMONA, "La responsabilidad del Estado-juez", cit. nota $n^{\circ} 12$, p. 350 . Veremos con más detalle esto en la próxima sección.

19 BALLIVIAN, "Responsabilidad", cit. nota $\mathrm{n}^{\circ} 18$; BARROS, Tratado, cit. nota $\mathrm{n}^{\circ} 17$; CALDERA, "Interpretación", cit. nota $\mathrm{n}^{\circ} 12$; CARMONA, "La responsabilidad del Estado-juez", cit. nota n ${ }^{\circ} 12$; CORDERO, Luis, “¿En qué estamos con la responsabilidad por error judicial?”, El Mercurio Legal, 25 de junio de 2014, en: http://www.elmercurio.com/Legal/Noticias/Analisis-Juridico/2014/06/25/En-que-estamoscon-la-responsabilidad-por-error-judicial.aspx [visitado el 18.01.2019]; DÍAZ, "La responsabilidad", cit. nota n⿳109; GARRIDO, "La Indemnización", cit. nota nº 17; FERNÁNDEZ, Miguel Ángel, La nueva justica penal frente a la constitución, Santiago: Lexis Nexis, 2006, passim; INSTITUTO NACIONAL DE DERECHOS HUMANOS, Informe anual 2014: situación de los derechos humanos en Chile, Santiago: Instituto Nacional de Derechos Humanos, 2015, pp. 84-86; ZÚÑIGA, Francisco, "La Acción de indemnización por error judicial. Reforma constitucional. regulación infraconstitucional y jurisprudencia”, Estudios Constitucionales, año 6, n² (2008), pp. 15-41, passim.

${ }^{20}$ Con todo, este efecto se habría morigerado en los últimos años tratándose de la interpretación que se ha dado al alcance de la regla que establece que la persona haya sido "sometida a proceso" En esta materia se ha producido una evolución relevante en la jurisprudencia en años recientes. Así, desde el año 2.000 hasta mediados del año 2014 la Corte Suprema sostuvo como regla que esta cláusula no era aplicable al funcionamiento del nuevo sistema acusatorio ya que éste no contemplaba una institución equivalente al auto de procesamiento del sistema inquisitivo. De esta forma se rechazaron múltiples solicitudes de declaración previa de personas que estuvieron privadas de libertad por decisiones muy discutibles de diversos jueces y que, finalmente, fueron absueltas o sobreseídas (por ejemplo, causa rol n ${ }^{\circ}$ 5270-2008 de 21 de enero de 2009). La Corte Suprema tuvo un cambio radical de doctrina jurisprudencial en este tema el año 2014 al aceptar que esta expresión no podía restringirse sólo a una institución específica del sistema inquisitivo antiguo y cubría a imputados en el nuevo sistema que eran objeto de medidas cautelares personales (causa rol n 4921-2014 de 9 de junio de 2014). Bajo este nuevo criterio la Corte acogió la solicitud declaración previa de error judicial que habilitó al recurrente a demandar la indemnización de perjuicios por haber estado en prisión preventiva y luego en arresto nocturno domiciliario en el desarrollo del proceso (causa rol $\mathrm{n}^{\circ} 1579-15$ de 8 de julio de 2015) (CORDERO, Eduardo, "La ampliación de responsabilidad del Estado juez a propósito de las sentencias de la Corte Suprema en materia de medidas cautelares privativas de libertad y los errores judiciales fuera del ámbito penal", en: VAN WEEZEL, Alex, et. al, Sentencias destacadas 2015, Santiago: Ediciones Libertad y Desarrollo, 2016, pp. 15-35, passim). Con todo, este cambio no se ha traducido en la práctica en un incremento significativo del número de casos en los que la Corte haya acogido la solicitud de declaración previa del error judicial. En parte importante por la persistencia de la cláusula e interpretación restrictiva de que las resoluciones deben haber sido "injustificadamente erróneas o arbitrarias". DUCE, Mauricio, "La indemnización por error judicial y las medidas cautelares personales: la consolidación de una nueva doctrina de parte de la Corte Suprema", El Mercurio Legal, 2015, passim. La buena noticia es que a la luz de esta nueva interpretación de la Corte serían potencialmente indemnizables las imputaciones erróneas que generaron privación o restricción a la libertad (medidas cautelares del art. 155 del CPP). 
Esta visión crítica del rendimiento de esta institución para reparar a las víctimas de los errores judiciales ha sido recogida por el legislador nacional ya que entre 2007 y 2017 es posible identificar al menos diez proyectos de reforma constitucional o legal destinados a flexibilizar la actual regulación, aun cuando ninguno de ellos ha prosperado a la fecha. ${ }^{21}$ En todo caso, un elemento común de estos proyectos sería que descansan como un supuesto básico la necesidad de ampliar el margen de la regulación actual frente a un diagnóstico crítico de su uso. Lamentablemente no se invocan antecedentes de corte empírico muy precisos sobre lo mismo.

Un análisis de la base de datos proporcionada por la Dirección de Estudios de la Corte Suprema (en adelante DECS) en la materia puede ayudar a tener una visión con fundamento empírico sobre este punto. Así, los datos proporcionados nos han permitido establecer el flujo total de casos presentados entre el año 1980 y marzo de $2018 .^{22}$ Para efectos de esta presentación dividimos los casos según el sistema procesal que dio origen a la solicitud (inquisitivo o acusatorio). Los resultados se exponen en la tabla $\mathrm{n}^{\circ} 1$.

Tabla $n^{\circ} 1$ :

Solicitudes de indemnización por error judicial período 1980-2018 (marzo)

Fuente: Elaboración propia sobre la base de datos de la DECS

\begin{tabular}{|l|c|}
\hline Tipo sistema & $\mathbf{N}^{\circ}$ solicitudes y \% \\
\hline Sistema inquisitivo & $112(80 \%)$ \\
\hline Sistema acusatorio & $28(20 \%)$ \\
\hline Total período & $\mathbf{1 4 0}(\mathbf{1 0 0 \%})$ \\
\hline
\end{tabular}

Llama la atención el bajo número de solicitudes en el período, las que apenas sobrepasarían las cinco como promedio anual. Esto hablaría de un escaso uso de este mecanismo, el cual podría deberse, entre otras razones, a lo que la doctrina mayoritaria ha sostenido sobre lo limitado de esta herramienta. En todo caso, un análisis en el tiempo da cuenta de un uso cada vez más creciente. Así, entre los años 1980 y 1990 sólo hubo dos solicitudes ante la Corte. Entre 1991 y el año 2000 esto subió a 31 (promedio de tres solicitudes anuales); entre 2001 y 2010 llegó a 60 (promedio de 6 anuales considerando ya ambos sistemas procesales) y desde 2011 a 2017 hubo 46 (promedio 6,5 anuales).

De acuerdo a esta misma base de datos es posible identificar que se habría acogido la solicitud de declaración previa por parte de la Corte Suprema en sólo ocho de ellas (cuatro desde 2007), es decir, en un 5,7\% del total. Como se puede apreciar, se trata de un número muy bajo incluso comparado con el de los recursos de revisión acogidos por la propia Corte

\footnotetext{
${ }^{21}$ Cuatro de estos proyectos ya están archivados: Boletines nº5539-07 de 2007; $\mathrm{n}^{\circ}$ 5745-07 de 2008; $\mathrm{n}^{\circ} 7.277-$ 07 de 2010; y, n 9.634-07 de 2014. Cinco están en tramitación, pero no han superado en primer trámite constitucional en la Cámara de Diputados: Boletines n 6083-07 de 2008; n 6310-07 de 2009; $n^{\circ} 7699-07$ de 2011; n 9513-07 de 2014; y, n 11.464-07 de 2017. Finalmente, hay un proyecto aprobado por la Cámara de Diputados y enviado al Senado para discusión: Boletín n¹1342-07 de 2017.

${ }^{22}$ En estricto rigor el primer ingreso a la Corte en esta materia aparece en el año 1985, por lo que en los años previos no habría sido objeto de uso.
} 


\section{Polít. Crim. Vol. 14, No 28 (Diciembre 2019), Art. 6, pp. 216-268. [http://politcrim.com/wp-content/uploads/2019/12/Vol14N28A6.pdf]}

según ya mencionamos. Todo esto ratificaría lo que ha venido sosteniendo la doctrina en la materia. ${ }^{23}$

Como complemento de lo anterior, información obtenida ante el Consejo de Defensa del Estado por solicitud de transparencia en diciembre del año 2017 indica que a esa fecha no existiría ningún caso del sistema procesal acusatorio en el que se hubiera pagado efectivamente una indemnización de parte del Estado por error judicial. ${ }^{24}$ Estas cifras indicarían que la posibilidad real de obtener indemnizaciones por errores judiciales conforme a la cláusula en análisis es excepcionalísima o casi marginal.

\section{Caracterización general de los casos en el período 2006-2017}

En la presente sección se presentan los resultados del análisis de las resoluciones dictadas por la Corte Suprema sobre la declaración previa a la indemnización por error judicial desde el 1 de enero del 2006 al 31 de diciembre del 2017. Dicho análisis fue realizado a partir de la base de datos entregada DECS. ${ }^{25}$

Antes de presentar dichos resultados, es necesario realizar algunas precisiones de orden metodológico. En primer lugar, la investigación se basa exclusivamente en la lectura de las resoluciones de la Corte Suprema sobre la declaración previa a la indemnización por error judicial y no contempla otros documentos o etapas del proceso de indemnización. En segundo lugar, corresponde explicar brevemente el proceso de trabajo seguido. Una vez identificadas las resoluciones, se tabularon datos cuantitativos de cada caso y luego se identificaron los principales temas tratados en cada una de ellas de manera de crear una base de datos en que se indica el número de rol de las resoluciones y considerandos específicos que incluyen un debate sobre ellos. Con esta base de datos, se analizó cada tema por separado, leyendo las resoluciones y considerandos anotados, identificando los argumentos de la Corte y las partes, buscando semejanzas, patrones, evoluciones, etc. Finalmente, cabe señalar que en este trabajo se ordenan las resoluciones según su número de rol, que corresponde al año de ingreso de la solicitud y no el año en que se pronuncia la resolución.

Hechas estas aclaraciones, la tabla $\mathrm{n}^{\mathrm{o}} 2$ contiene un resumen del número de ingresos de solicitudes presentadas ante la Corte Suprema para obtener la declaración previa que exige el artículo 19 n $^{\circ} 7$ letra i), divididas por año, desde el 2006 al 2017.

\footnotetext{
${ }^{23}$ Cabe señalar que existe otra vía para que la Corte Suprema haga también esta declaración previa. En el caso de acoger un recurso de revisión en contra de una sentencia firme, la Corte podría pronunciarse en forma inmediata sobre la procedencia de la indemnización según lo dispone el artículo 478 inciso final del Código Procesal Penal. No consideramos estos casos en el desarrollo de esta investigación, aun cuando al menos tenemos conocimiento de uno del sistema acusatorio en el que la Corte realizó la declaración previa (rol $\mathrm{n}^{\circ}$ 44270-2017 a favor de Marcos Cofré). Nuestro foco como ya ha sido expresado en el texto principal estará en las solicitudes específicas presentadas ante la Corte por el artículo 19 n 7 letra i) de la Constitución.

${ }^{24}$ Oficio Ordinario $\mathrm{n}^{\circ} 05145$ de 27 de diciembre de 2017. En el sistema inquisitivo se registrarían sólo dos casos en que se habría indemnizado efectivamente a la víctima de error judicial en una causa ejecutoriada (causa rol $\mathrm{n}^{\circ}$ 20.189-2012 del 14 Juzgado Civil de Santiago y causa rol $\mathrm{n}^{\circ} 14666-2015$ del $9^{\circ}$ Juzgado Civil de Santiago) desde el año 2005. Ambos casos serán objeto de análisis en la sección 5.

${ }^{25}$ El listado completo de causas señaladas por la Dirección de Estudios de la Corte Suprema y revisadas en este trabajo puede encontrarse en el Anexo.
} 
Tabla $\mathrm{n}^{\circ} 2$

Solicitudes ingresadas a la Corte Suprema, años 2006-2017

Fuente: Elaboración propia sobre la base de datos de la DECS

\begin{tabular}{|l|c|c|}
\hline \multicolumn{1}{|c|}{ Añ } & $\mathbf{N}^{\circ}$ & $\mathbf{\%}$ \\
\hline 2006 & 11 & $14,3 \%$ \\
\hline 2007 & 4 & $5,2 \%$ \\
\hline 2008 & 8 & $10,4 \%$ \\
\hline 2009 & 3 & $3,9 \%$ \\
\hline 2010 & 9 & $11,7 \%$ \\
\hline 2011 & 4 & $5,2 \%$ \\
\hline 2012 & 8 & $10,4 \%$ \\
\hline 2013 & 5 & $6,5 \%$ \\
\hline 2014 & 10 & $13 \%$ \\
\hline 2015 & 4 & $5,2 \%$ \\
\hline 2016 & 7 & $9,1 \%$ \\
\hline 2017 & 4 & $5,2 \%$ \\
\hline Total & $\mathbf{7 7}$ & $\mathbf{1 0 0 \%}$ \\
\hline
\end{tabular}

El universo en estudio da cuenta de la escasa cantidad de solicitudes presentadas en el período, que da un promedio de 6,4 solicitudes anuales, pero que como veíamos con anterioridad ha representado un alza de lo que ocurrió entre los años 1980 y 1999. También señalábamos que estos números no concuerdan con la cantidad de casos en que potencialmente se podría haber reclamado indemnización. Por ejemplo, según la Defensoría Penal Pública, sólo entre el 2015 y 2017 se decretó prisión preventiva a 8.596 personas que posteriormente no fueron condenadas $^{26}$ y que, por tanto, podrían haber ejercido potencialmente la solicitud en estudio. ${ }^{27}$ Por otro lado, también hay que sumar los 48 casos de sistema penal acusatorio en que la sentencia condenatoria fue revocada por la Corte Suprema luego de un recurso de revisión en el período 2007-2016 que ya hemos citado, entre otros universos posibles.

Un factor que explicaría este fenómeno estaría en la disposición de la Corte Suprema a rechazar estas solicitudes, lo que desincentivaría su utilización. Como se señalará más adelante, en el período de 12 años estudiado en este trabajo sólo cuatro solicitudes fueron acogidas por la Corte Suprema, lo que representa un 6,1\% del total de solicitudes resueltas en este período. A estas sentencias favorables, se suman otras cuatro identificadas reiteradamente por la doctrina en el período 1980 a $2005^{28}$. Es decir, en los 38 años que han

\footnotetext{
${ }^{26}$ Balance de Gestión Institucional del 2017 de la Defensoría Penal Pública.

${ }^{27}$ Para efectos del ejercicio, nos ponemos en el escenario que sólo en un 5\% de dichos casos (uno de cada 20) pude haberse cometido un error grave o una arbitrariedad (se trata de un porcentaje de error sugerido por las investigaciones empíricas en los Estados Unidos de RISINGER, "Innocent", cit. nota n 4 y GROSS, "Rate", cit. nota $\left.\mathrm{n}^{\circ} 4\right)$. Eso daría un universo potencial de 430 casos.

${ }^{28}$ Salinas Gómez con Fisco (rol n 24518 de 15 de noviembre de 1985); Araya Molina con Fisco (rol $n^{\circ}$ 23.833 de 25 de julio de 1989); Vegas Rojas con Fisco (rol n 27662 de 5 de diciembre de 1990); y, Márquez Fuentes con Fisco (rol n 802 de 1999), según CARMONA, "La responsabilidad del Estado-juez”, cit. nota
} 


\section{Polít. Crim. Vol. 14, No 28 (Diciembre 2019), Art. 6, pp. 216-268. [http://politcrim.com/wp-content/uploads/2019/12/Vol14N28A6.pdf]}

transcurrido desde que aparece esta norma en la Constitución de 1980, sólo ocho veces se ha obtenido la declaración exigida por el artículo 19 nº7 letra i) de la Constitución, lo que equivale aproximadamente a una solicitud exitosa cada casi cinco años.

Además, existe otro filtro importante que se verifica incluso antes de la intervención de la Corte. En efecto, de las 77 solicitudes del período en estudio, 11 no llegaron a ser objeto de pronunciamiento por parte de la Corte. Específicamente, seis fueron archivadas, dos se acumularon, dos fueron tenidas como no presentadas y una fue desistida. ${ }^{29}$ Esta forma de término sin resolución de la Corte corresponde al 14,3\% del total de solicitudes presentadas en el período, es decir, del promedio de 6,4 solicitudes presentadas por año, una de ellas fracasa antes de ser resuelta. Estamos, por lo tanto, en presencia de otra potencial dificultad para el ejercicio del derecho a indemnización por error judicial. Sin embargo, el presente trabajo no abarca un análisis de estas solicitudes, precisamente porque no hay un pronunciamiento de la Corte Suprema sobre ellas.

En este trabajo se analizarán las resoluciones que recaen sobre las 66 solicitudes que sí fueron objeto de pronunciamiento por parte de la Corte. La tabla $\mathrm{n}^{\mathbf{0}} 3$ presenta los casos por año y por alguno de los tres tipos término: inadmisibles, rechazadas y acogidas.

Tabla $\mathrm{n}^{\circ}$ 3:

Tipo de término de las solicitudes resueltas por año, años 2006-2017

Fuente: Elaboración propia sobre la base de datos de la DECS

\begin{tabular}{|c|c|c|c|c|}
\hline Año & Rechazadas & Inadmisibles & Acogidas & Total y \% \\
\hline $\mathbf{2 0 0 6}$ & 8 & 1 & 0 & $9(13,6 \%)$ \\
\hline $\mathbf{2 0 0 7}$ & 4 & 0 & 0 & $4(6,1 \%)$ \\
\hline $\mathbf{2 0 0 8}$ & 7 & 1 & 0 & $8(12,2 \%)$ \\
\hline $\mathbf{2 0 0 9}$ & 2 & 0 & 0 & $2(3 \%)$ \\
\hline $\mathbf{2 0 1 0}$ & 8 & 0 & 1 & $9(13,6 \%)$ \\
\hline $\mathbf{2 0 1 1}$ & 2 & 1 & 0 & $3(4,5 \%)$ \\
\hline $\mathbf{2 0 1 2}$ & 5 & 0 & 0 & $5(7,6 \%)$ \\
\hline $\mathbf{2 0 1 3}$ & 1 & 2 & 0 & $3(4,5 \%)$ \\
\hline $\mathbf{2 0 1 4}$ & 4 & 5 & 1 & $10(15,1 \%)$ \\
\hline $\mathbf{2 0 1 5}$ & 1 & 2 & 1 & $4(6,1 \%)$ \\
\hline $\mathbf{2 0 1 6}$ & 3 & 2 & 0 & $5(7,6 \%)$ \\
\hline $\mathbf{2 0 1 7}$ & 1 & 2 & 1 & $4(6,1 \%)$ \\
\hline Total & $\mathbf{4 6}(\mathbf{6 9 , 7 \% )}$ & $\mathbf{1 6}(\mathbf{2 4 , 2 \% )}$ & $\mathbf{4 ( 6 , 1 \% )}$ & $\mathbf{6 6}(\mathbf{1 0 0 \% )}$ \\
\hline
\end{tabular}

Como ya señalábamos, llama la atención la escasa cantidad de solicitudes acogidas que representan tan sólo el 6,1\% del total de las resueltas. Los rechazos alcanzan el 69,7\% de

n¹2, pp. 350-352; DÍAZ, “La responsabilidad”, cit. nota $\mathrm{n}^{\circ} 19$, p. 40. Ballivian sólo menciona a las tres primeras, no incluyendo a la de Márquez Fuentes con Fisco (BALLIVIAN, "Responsabilidad", cit. nota n¹8, p. 54).

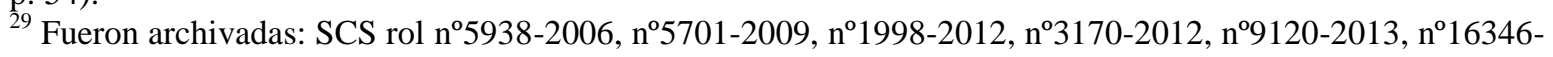
2013. Fueron acumuladas: SCS n92767-2016 y n92769-2016. Fueron tenidas como no presentadas: SCS rol n³481-2006 y n9957-2011. Fue desistida: SCS rolº8050-2012. 
las solicitudes. Por otro lado, el bajo porcentaje de casos acogidos también se debe, en alguna medida, a una barrera formal dada por los requisitos de admisibilidad impuestos por el Auto Acordado de la Corte Suprema que regula esta materia, que lleva a la Corte a declarar inadmisibles el $24,2 \%$ de las solicitudes. Volveremos sobre este tema un poco más adelante.

Junto con estos datos generales, el análisis de nuestro universo nos permitió obtener información general de los casos, tales como el género de los solicitantes, el tipo de perjuicios que sufrieron en virtud de lo que consideran ha sido un "error judicial", el delito o delitos que se les ha imputado, el tipo de resoluciones que se impugnan, el sistema en que han sido dictadas, los tribunales que las dictaron, etc. Estos datos son relevantes ya que permiten comprender mejor de qué tratan los casos en que se alega la existencia de un error judicial, de manera de contextualizar los razonamientos de la Corte que estudiaremos en las próximas secciones.

Un primer dato interesante es el número y género de las personas que solicitan a la Corte Suprema la declaración previa a la indemnización por error judicial. Al respecto, resulta que, de las 66 resoluciones estudiadas, en una de ellas no había información sobre el número o género de él o los solicitantes. ${ }^{30}$ En las 65 solicitudes restantes, un primer hallazgo es que, en varias solicitudes, concurría más de una persona a solicitar la declaración previa, de manera que existirían 77 solicitantes que piden la declaración en cuestión a la Corte por medio de 65 solicitudes. De ellos un 14,3\% correspondía a mujeres y $85,7 \%$ a hombres solicitantes. La proporción de hombres y mujeres solicitantes es relativamente similar a la del sistema en general en calidad de imputados. En efecto, el promedio de imputadas atendidas por la Defensoría Penal Pública en el período 2006-2017 es de $18 \%$ y de imputados corresponde a un $82 \%$.

Otros hallazgos se relacionan con la cantidad y tipo de delitos por los que los solicitantes alegan haber sido condenados o procesados en forma injustificadamente errónea o arbitraria. De las 66 resoluciones estudiadas, ocho de ellas no ofrecen información sobre la cantidad o tipo de delitos imputados, mientras que en las 58 restantes se identifican 82 delitos. Es decir, en varios casos él o los solicitantes eran imputados por dos o más delitos. En cuanto al tipo de delitos involucrados, existe una amplia variedad y ninguna tendencia de peso especial de alguna categoría específica. La tabla $n^{\circ} 4$ presenta el resumen de los delitos agrupados en sus principales categorías.

\footnotetext{
${ }^{30}$ No aportaba estos datos resolución que declara inadmisible la solicitud rol $\mathrm{n}^{\mathrm{0}} 32208-2014$ y no fue posible encontrarlos por ser reservada. Tampoco aportaban estos datos las resoluciones rol n⿳07478-2013 y n⿳10127252011, sin embargo, fue posible encontrar esta información en la consulta unificada de causas de la página web del Poder Judicial.
} 
Tabla $n^{\circ} 4$ :

Categoría de delitos agrupados por categorías, años 2006-2017

Fuente: Elaboración propia

\begin{tabular}{|l|c|c|}
\hline Categoría delitos & $\mathbf{N}^{\circ}$ & $\mathbf{\%}$ \\
\hline Contra la propiedad & 12 & $14,6 \%$ \\
\hline Sexuales & 9 & $11 \%$ \\
\hline Ley de control de armas & 8 & $9,8 \%$ \\
\hline Ley ${ }^{\circ} 20.000$ (drogas) & 7 & $8,5 \%$ \\
\hline Falsificación & 7 & $8,5 \%$ \\
\hline Contra las personas & 6 & $7,3 \%$ \\
\hline Código de Justicia Militar & 6 & $7,3 \%$ \\
\hline Estafa y otros engaños & 5 & $6,1 \%$ \\
\hline Funcionarios & 5 & $6,1 \%$ \\
\hline Otros & 17 & $20,7 \%$ \\
\hline Total & $\mathbf{8 2}$ & $\mathbf{1 0 0 \%}$ \\
\hline
\end{tabular}

Como se puede apreciar, no existe una tendencia clara hacia una categoría de delitos respecto de los que las personas sientan haber sido condenados o procesados en forma injustificadamente errónea o arbitraria. Por lo tanto, la indemnización por error judicial pareciera no tener relación con categorías de delito en específico, sino netamente con los "errores" que se producen en un caso concreto.

Otro dato de interés identificado en la investigación se vincula al tipo de sistema procesal (inquisitivo o acusatorio) en que se produce la resolución supuestamente errónea o arbitraria. De ellas, 31 fueron emanadas del sistema inquisitivo (47\%), 28 del sistema acusatorio $(42,4 \%)$ y en siete casos $(10,6 \%)$ no se obtuvo información que permitiera discriminar. Si se compara con los resultados de la tabla $\mathrm{n}^{\circ} 1$, hay un aumento significativo de los casos del sistema acusatorio, lo que se explica debido a que en el período seleccionado para esta investigación éste ya se encontraba funcionando en régimen. En esta dirección, desde el 2014 la cantidad de resoluciones examinadas del sistema inquisitivo no ha superado las del sistema acusatorio. Ello daría cuenta de que los casos del sistema inquisitivo se han ido extinguiendo con el paso de los años y, probablemente, tengan cada vez menos presencia hasta desparecer definitivamente.

Durante la investigación también se intentó identificar el tipo de procedimiento en que se dicta la resolución "impugnada" dentro de los distintos tipos que existen en el Código Procesal Penal (en adelante el CPP). Lamentablemente, de las 28 resoluciones impugnadas del sistema acusatorio, en 16 sentencias no había información al respecto, por lo que sólo se obtuvieron datos de las 12 restantes. De ellas, seis resoluciones impugnadas fueron dictadas en procedimiento ordinario, tres en simplificado, dos en monitorio $\mathrm{y}$, finalmente, una en abreviado. Debido a que en menos de la mitad del universo potencial de casos pudimos identificar el tipo de procedimiento, no nos parece conveniente adelantar alguna conclusión en este punto ni presentar el dato en alguna tabla.

Otro dato de interés que recogimos en la investigación fue el de identificar el tipo de resolución que se señala como "injustificadamente errónea o arbitraria" por el solicitante. 
En este punto, de las 66 sentencias examinadas, cinco no contenían información del tipo de resolución impugnada, por lo que nos focalizamos en las 61 restantes. Ellas resolvieron solicitudes que, en total, impugnan 100 resoluciones. Ello se explica porque en varias solicitudes se pedía que la Corte declarara injustificadamente errónea y/o arbitraria más de una resolución. La tabla $\mathrm{n}^{\circ} 5$ resume los resultados obtenidos mostrando la distribución de resoluciones impugnadas.

Tabla $\mathrm{n}^{\circ}$ 5:

Tipo de resoluciones impugnadas, años 2006-2017

Fuente: Elaboración propia

\begin{tabular}{|l|c|c|}
\hline Tipo de resolución & $\mathbf{N}^{\circ}$ & $\mathbf{\%}$ \\
\hline Auto de Procesamiento & 28 & $28 \%$ \\
\hline Definitiva de primera instancia & 25 & $25 \%$ \\
\hline Definitiva de segunda instancia & 2 & $2 \%$ \\
\hline Medidas cautelares & 32 & $32 \%$ \\
\hline Prisión preventiva & 16 & $16 \%$ \\
\hline Rechazo revocación prisión prev. & 10 & $10 \%$ \\
\hline Arresto domiciliario & 4 & $4 \%$ \\
\hline Detención & 1 & $1 \%$ \\
\hline Prohibición acercarse víctima & 1 & $1 \%$ \\
\hline Otros & 13 & $13 \%$ \\
\hline Acusación & 4 & $4 \%$ \\
\hline Formalización investigación & 4 & $4 \%$ \\
\hline Rechazo cautela garantías & 2 & $2 \%$ \\
\hline Auto acusatorio & 1 & $1 \%$ \\
\hline Rechazo sobreseimiento def. & 1 & $1 \%$ \\
\hline Denuncia & 1 & $1 \%$ \\
\hline Total & $\mathbf{1 0 0}$ & $\mathbf{1 0 0 \%}$ \\
\hline
\end{tabular}

Los tipos de resoluciones se distribuyen de modo más o menos homogéneo entre los autos de procesamiento, sentencias definitivas de primera instancia y resoluciones sobre medidas cautelares, lo que se explica por el importante peso que aún tienen los casos del sistema inquisitivo en el período en estudio. Sin embargo, la mayor cantidad de resoluciones impugnadas son sobre medidas cautelares, a pesar de -como ya mencionamos- la Corte excluyó hasta el 2014 la posibilidad de indemnizar por error judicial resoluciones que decretan medidas cautelares en el sistema acusatorio producto de la interpretación que sostuvo de "sometido a proceso".

En relación a las 27 sentencias definitivas de primera o segunda instancia (todas condenatorias), sólo 19 resoluciones ofrecen información sobre la sanción impuesta por aquellas. De ellas, dos imponen pena de multa y 17 imponen como sanción principal una pena privativa de libertad. La baja cantidad de sentencias impugnadas que imponen sólo pena de multa mostraría que sólo quienes son objeto de consecuencias más graves (penas privativas de libertad) son aquellos que tienen más incentivos para utilizar este mecanismo. 


\section{Polít. Crim. Vol. 14, No 28 (Diciembre 2019), Art. 6, pp. 216-268.

Otro tema que fue objeto de nuestra investigación, consistió en identificar al tribunal o juez que pronuncia la resolución impugnada. De ellas, ocho no contienen información y 58 sí. En estos casos se identificaron impugnaciones a decisiones de 60 autoridades judiciales diferentes. La tabla $n^{\circ} 6$ resume los hallazgos en esta materia.Tabla $\mathrm{n}^{\circ} 6$ :

Tribunales que pronuncias resoluciones impugnadas, años 2006-2017

Fuente: Elaboración propia

\begin{tabular}{|c|c|c|}
\hline Tribunal & $\mathbf{N}^{\circ}$ & $\%$ \\
\hline Juez de Garantía & 22 & $36,7 \%$ \\
\hline Juez del Crimen & 17 & $28,3 \%$ \\
\hline Autoridades Militares $^{31}$ & 8 & $13,3 \%$ \\
\hline Tribunal Oral en lo Penal & 6 & $10 \%$ \\
\hline Juez de Letras & 3 & $5 \%$ \\
\hline Corte de Apelaciones & 2 & $3,3 \%$ \\
\hline Ministro de Fuero & 2 & $3,3 \%$ \\
\hline Total & 60 & $100 \%$ \\
\hline
\end{tabular}

Como se puede observar, existe una dispersión importante entre diversos tribunales, pero con una mayor presencia de jueces de garantía y del crimen, lo que es consistente con los tipos de procedimiento y resoluciones que se impugnaron que revisamos previamente.

Como hemos venido adelantando, uno de los aspectos más sensibles en la interpretación que ha realizado la Corte Suprema en esta materia es el alcance que tenga que una resolución judicial pueda ser "injustificadamente errónea" o "arbitraria". Es por eso que también identificamos los "vicios" por los que los requirentes recurrían ante la Corte. Así, determinamos si se invocaba algunos de ellos o ambos en su conjunto. En este contexto, en 12 de las 66 resoluciones estudiadas no hay información sobre el defecto que tendría la resolución según el solicitante. Por otro lado, en ocho resoluciones no se especifica si la resolución impugnada sería injustificadamente errónea y/o arbitraria según la solicitud, limitándose a señalar que se verifica un "error judicial". A continuación, en la tabla $\mathrm{n}^{\circ} 7$, se analizan las 46 sentencias que sí contienen información al respecto, indicando el "vicio" que le atribuye la solicitud a la resolución impugnada (según reporta la sentencia de la Corte) y la cantidad de solicitudes en cada caso.

\footnotetext{
${ }^{31}$ Estas incluyen a Tribunales Militares en Tiempos de Guerra, Fiscalía Militar y Corte Marcial.
} 
DUCE, Mauricio; VILLARROEL, Romina, "Indemnización por error judicial: una aproximación empírica a la jurisprudencia de la Corte Suprema de los años 2006-2017”

Tabla $\mathrm{n}^{\circ}$ 7:

Vicios atribuidos a resoluciones impugnadas, años 2006-2017

Fuente: Elaboración propia

\begin{tabular}{|l|c|c|}
\hline Tipo de vicio resolución & $\mathbf{N}^{\circ}$ & \% \\
\hline Injustificadamente errónea o arbitraria & 24 & $52,2 \%$ \\
\hline Injustificadamente errónea y arbitraria & 7 & $15,2 \%$ \\
\hline Injustificadamente errónea y/o arbitraria & 8 & $17,4 \%$ \\
\hline Injustificadamente errónea & 4 & $8,7 \%$ \\
\hline Arbitraria & 2 & $4,3 \%$ \\
\hline Injusta $^{32}$ & 1 & $2,2 \%$ \\
\hline Total & $\mathbf{4 6}$ & $\mathbf{1 0 0 \%}$ \\
\hline
\end{tabular}

Estos últimos datos dan cuenta sobre un problema relevante identificado en la investigación relacionado con la imprecisión de los solicitantes al pedir la declaración previa al error judicial. Como puede observarse, sólo seis de ellos (13\%) especifican cuál de los dos "vicios" posibles adolece la resolución que impugnan, en cambio, la gran mayoría se limita a repetir la fórmula "injustificadamente errónea o arbitraria" que utiliza textualmente la norma constitucional $\mathrm{o}$, incluso, atribuir ambos vicios conjunta o alternativamente, señalando en algunas ocasiones que la resolución es injustificadamente errónea "o" arbitraria y, luego, que es injustificadamente errónea " $y$ " arbitraria. Ello es un defecto importante de las solicitudes, puesto que, como veremos más adelante, ambos conceptos han sido entendidos por la Corte como dos supuestos diferentes que tienen definiciones independientes. En este sentido, si la mayoría de las solicitudes no explicita cuál es el vicio específico del que adolece la sentencia impugnada, mucho menos están en condiciones de argumentar concretamente porqué la sentencia sería "injustificadamente errónea", "arbitraria" o ambos, si así lo estima. En este mismo sentido, resulta criticable que sólo en cuatro casos el solicitante ofrezca algún tipo de definición de estos conceptos. Esta situación es especialmente preocupante si consideramos que el objetivo de esta solicitud es precisamente persuadir a la Corte para que declare que la resolución es "injustificadamente errónea", "arbitraria", o ambas, si es que se dan ambos supuestos. En consecuencia, una explicación complementaria al bajo porcentaje de solicitudes acogidas por la Corte podría deberse al mal trabajo de abogados litigantes, hipótesis que hasta el momento no ha sido recogida por la doctrina como una causa explicativa del fenómeno y que nos parece a la luz de estos resultados debiera considerarse con más cuidado.

Otro elemento central en la configuración del artículo $19 \mathrm{n}^{\circ} 7$ letra i) está en la exigencia que el solicitante haya sido beneficiado por sentencia absolutoria o sobreseimiento definitivo. Encontramos información sobre esta materia en 60 de los 66 casos. La tabla n ${ }^{\circ} 8$ resume los resultados.

\footnotetext{
${ }^{32}$ En esta resolución, el solicitante exige que la Corte Suprema declare que fue "injustamente privado de libertad".
} 
Tabla $\mathrm{n}^{\circ}$ 8:

Tipo de término del caso, años 2006-2017

Fuente: Elaboración propia

\begin{tabular}{|l|c|c|}
\hline Tipo de término & $\mathbf{N}^{\circ}$ & $\mathbf{\%}$ \\
\hline Absolutoria de primera instancia & 26 & $43,3 \%$ \\
\hline Absolutoria de segunda instancia & 24 & $40 \%$ \\
\hline Sobreseimiento definitivo & 7 & $11,7 \%$ \\
\hline Otras & 3 & $5 \%$ \\
\hline Acoge recurso de amparo & 1 & $1,7 \%$ \\
\hline Sobreseimiento temporal & 1 & $1,7 \%$ \\
\hline Condenatoria de primera instancia & 1 & $1,7 \%$ \\
\hline Total & $\mathbf{6 0}$ & $\mathbf{1 0 0 \%}$ \\
\hline
\end{tabular}

Finalmente, en relación a los perjuicios sufridos por los solicitantes, 39 (59\%) de ellos alegan haber sido sometidos a alguna forma de privación de libertad (ya sea prisión preventiva o detención), de los cuales, ocho señala, además, haber sido sometido a alguna forma de afectación de libertad (arresto domiciliario total, nocturno, firma y arraigo). Las privaciones de libertad descritas van desde un día de detención a seis años de prisión preventiva. Por otro lado, tres solicitantes describen únicamente haber sido sometidos a alguna forma de afectación de la libertad (arraigo, prohibición de acercarse a la víctima y libertad provisional). Para terminar, 10 solicitantes describen otro tipo de perjuicios, como daño moral, patrimonial, emergente, a su salud, calidad de vida familiar, profesional y social, destitución de su puesto de trabajo, entre otros.

En suma, los casos que llegan a esta instancia son sumamente variados. Como hemos visto en esta sección, no existe una tendencia importante en los delitos que les fueron imputados a los solicitantes, en las resoluciones que se impugnan ni en el tipo de sistema en que fueron dictados. Por otro lado, la tendencia en el género de los solicitantes (casi el 86\% son hombres) sólo responde a la similar a la proporción que se verifica en el sistema procesal penal en general.

Sin embargo, existen algunas tendencias interesantes como, por ejemplo, que la mayoría de los solicitantes fue beneficiada con una sentencia absolutoria posterior mientras que una minoría fue sobreseída. Por otro lado, se han impugnado muchas más sentencias sobre medidas cautelares de las que se esperaría considerando la redacción de la norma y la jurisprudencia de la Corte Suprema durante buena parte de la vigencia del sistema acusatorio y que cubre la mayor parte del período objeto de estudio. Además, como se vio anteriormente, los casos que llegan a esta instancia son, en principio, los que han tenido consecuencias más graves del sistema. En efecto, casi la totalidad de solicitantes que reclaman de una sentencia definitiva fueron condenados a una pena privativa de libertad (la sanción más grave de nuestro ordenamiento jurídico). 
DUCE, Mauricio; VILLARROEL, Romina, "Indemnización por error judicial: una aproximación empírica a la jurisprudencia de la Corte Suprema de los años 2006-2017”

\section{Resoluciones que declaran inadmisible la solicitud de declaración previa de la Corte Suprema}

La presente sección tiene por objeto estudiar las 16 resoluciones del período 2006-2017 que declaran la inadmisibilidad de la solicitud de declaración previa a la indemnización por error judicial y que representan un $24,2 \%$ del total en dicho período. Específicamente, analizaremos las razones que llevaron a la Corte a declarar la inadmisibilidad y estudiaremos si el filtro de admisibilidad constituye o no una barrera para el ejercicio del derecho a una indemnización por error judicial.

Para analizar estas resoluciones, el primer paso fue distinguir entre dos tipos, que denominaremos "inadmisibilidades de forma" e "inadmisibilidades de fondo". De las 16 resoluciones que declaran inadmisible la solicitud, en 13 de ellas los argumentos fueron propiamente "de forma", es decir, declaran inadmisible la solicitud por no cumplir con alguno de los requisitos de admisibilidad contemplados en el artículo $1^{\circ}$ del Auto Acordado de la Corte Suprema o en el mismo artículo $19 \mathrm{n}^{\circ} 7$ letra i) de la Constitución. ${ }^{33}$ En este contexto, y como veremos hacia al final de esta sección, los requisitos de admisibilidad no parecen ser un obstáculo importante para el ejercicio de este derecho.

Por otro lado, tres resoluciones declaran inadmisible la solicitud por argumentos "de fondo", es decir, referidos a si la resolución impugnada fue injustificadamente errónea o arbitraria y no por incumplir los requisitos de admisibilidad que impone el Auto Acordado. Por esta razón, estimamos que la resolución correcta en dichos casos era declarar admisible el recurso, darle traslado al Fisco y a la Fiscalía Judicial y, luego, "rechazarlo" por no tratarse de una resolución injustificadamente errónea o arbitraria. Si esto hubiera sido así, produciría un efecto importante en los resultados generales que revisamos en la tabla ${ }^{\circ} 3$. En concreto, dichos requisitos pasan de ser un obstáculo para el $24,2 \%$ de los casos a serlo sólo para el $19,7 \%$ de ellos y los casos rechazados por razones de fondo subirían de un $69,7 \%$ a un $74,2 \%$.

A continuación, se estudiarán por separado las resoluciones que de declaran inadmisibilidad por motivos de forma y por motivos de fondo.

\subsection{Inadmisibilidades "de forma"}

En las 13 resoluciones que declaran inadmisible la solicitud por motivos de forma, la razón más frecuente para hacer dicha declaración es el incumplimiento del plazo de seis meses para presentar la solicitud desde que quede ejecutoriada la sentencia absolutoria o el auto de sobreseimiento, impuesto por el artículo $1^{\circ}$ del mencionado Auto Acordado. En concreto, siete solicitudes ${ }^{34}$ (9,1\% del total y 56,2\% del universo de inadmisibles) fueron declaradas inadmisibles por este motivo.

\footnotetext{
${ }^{33}$ En lo sustancial tal norma exige que las solicitudes sean presentadas dentro de los seis meses siguientes contados desde que quede ejecutoriada sentencia absolutoria o sobreseimiento definitivo y, además, adjuntar copias de un conjunto de documentos.

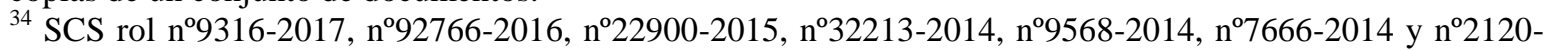
2008.
} 


\section{Polít. Crim. Vol. 14, No 28 (Diciembre 2019), Art. 6, pp. 216-268. [http://politcrim.com/wp-content/uploads/2019/12/Vol14N28A6.pdf]}

El segundo motivo más frecuente es el incumplimiento de la obligación de acompañar uno o más de los antecedentes señalados en las letras a)-e) del artículo $1^{\circ}$ del Auto Acordado. En concreto, tres solicitudes ${ }^{35}$ (4,5\% del total) omitieron este requisito. Una de ellas ${ }^{36}$ omitió adjuntar los documentos de las letras b y c), otra ${ }^{37}$ olvida adjuntar el documento señalado en la letra c) y, finalmente, otra solicitud ${ }^{38}$ no acompañó documento alguno.

Por otro lado, una de las solicitudes ${ }^{39}$ fue declarada inadmisible por no haber terminado la causa por sobreseimiento definitivo o una sentencia absolutoria (requisito impuesto por el mismo artículo $19 \mathrm{n}^{\circ} 7$ letra i), puesto que se trataba de un recurso de amparo.

Con respecto a las dos solicitudes ${ }^{40}$ restantes no fue posible determinar el motivo por el cual la Corte declara la inadmisibilidad. En una de ellas ${ }^{41}$ se decreta la inadmisibilidad por "no haberse dado estricto cumplimiento a lo que ordena el número $2^{\circ}$ del Auto Acordado", norma que no contiene requisitos, sino la orden de declarar inadmisible la solicitud que no cumpla con los requisitos del artículo $1^{\circ}$. En la resolución restante, ${ }^{42}$ se declara la inadmisibilidad "atendido el tiempo transcurrido sin que se haya dado cumplimiento a lo ordenado a fojas 65 " y puesto que la causa está sujeta a reserva, no fue posible conocer la causal específica de inadmisibilidad.

Como conclusión de estos hallazgos, hasta aquí no pareciera que la Corte Suprema tenga una actitud excesivamente formalista cuando conoce estas solicitudes, puesto que siete de las 13 inadmisibilidad de forma $(53,8 \%)$ son declaradas por ser extemporáneas, causal específicamente contemplada en el Auto Acordado y que cualquier sistema jurídico consideraría razonable para desechar una solicitud de esta naturaleza. Por otro lado, en tres ocasiones (23\%) se declara la inadmisibilidad de la solicitud por no acompañar los documentos básicos que se requieren para su resolución y que se encuentran detallados también en el Auto Acordado. En suma, en el al menos el 76,8\% de las inadmisibilidades de forma la Corte toma una decisión razonable que no podría calificarse como "formalista" o al menos "excesivamente formalista".

\subsection{Inadmisibilidades "de fondo"}

En las tres inadmisibilidades por motivos de fondo, ${ }^{43}$ se reclama sobre resoluciones de Juzgados de Garantía que decretan medidas cautelares de prisión preventiva, ${ }^{44}{ }^{3 i n}$

\footnotetext{
${ }^{35}$ SCS rol nº $47665-2016, n^{\circ} 14142-2013$ y n ${ }^{\circ} 5612-2006$.

${ }^{36}$ SCS rol n47665-2016.

${ }^{37}$ SCS rol n ${ }^{\circ} 5612-2006$.

${ }^{38}$ SCS rol no14142-2013.

${ }^{39} \mathrm{SCS}$ rol n ${ }^{\circ} 7478-2013$.

${ }^{40}$ SCS rol n⿳3 32208-2014 y nº $12725-2011$.

${ }^{41}$ SCS rol nº $12725-2011$.

${ }^{42}$ SCS rol n³2208-2014.

${ }^{43}$ SCS rol nº11730-2014, n9559-2015 y nº19263-2017.

${ }^{44}$ En la solicitud resuelta en SCS rol $\mathrm{n}^{\circ} 9559-2015$, el considerando primero señala que el solicitante deduce acción de indemnización por error judicial "respecto de la sentencia absolutoria dictada". Sin embargo, por
} 
especificar si el "vicio" del que adolece la resolución es un error injustificado, arbitrariedad o ambos, ${ }^{45}$ tampoco ofrecen un concepto de "error injustificado" o "arbitrariedad", ni especifican cómo la resolución cabría dentro de estos supuestos (todo ello según la información que entrega la Corte sobre la solicitud). Dos de estos casos ${ }^{46}$ basan su solicitud en haber sido declarada y mantenida la prisión preventiva -"hasta la absolución" en un caso, y "por dos años aproximadamente" en el otro, respectivamente-, siendo que la prueba del Ministerio Público fue declarada "insuficiente" por el Tribunal Oral en lo Penal que los absolvió. En uno de estos $\operatorname{casos}^{47}$, el solicitante alega haber sufrido daño moral por su avanzada edad y la traumática situación que vivió, daño emergente al no poder cobrar mensualmente su pensión y lucro cesante al no poder continuar con su trabajo. Por estas razones, estima que ha sido "injustamente privado de libertad". En este caso, pareciera que el solicitante reclama una suerte de derecho objetivo a ser indemnizado por absolución, ya que en la resolución de la Corte no se registran argumentos en orden a establecer que las resoluciones que lo afectaron fueran injustificadamente erróneas, arbitrarias o que adolecieran de algún tipo de defecto. En cambio, en el otro caso, ${ }^{48}$ el solicitante critica directamente la resolución que impugna, señalando que "existió un error de derecho por parte de la magistratura de San Bernardo y del Ministerio Público en cuanto ambos organismos tuvieron conocimiento de la falta de prueba que existía para acreditar la participación culpable del acusado lo que fue establecido finalmente por un fallo absolutorio". 49

Ante estas alegaciones, la Corte Suprema respondió que el artículo 19 de la Constitución confiere el derecho a reclamar indemnización de los perjuicios sufridos como consecuencia del sometimiento a proceso o condena injustificadamente erróneos o arbitrarios y, para calificar estas actuaciones de tal manera, se requiere que las resoluciones "carezcan en absoluto de elementos de convicción que permitan sustentarlas racionalmente o que han sido expedidas por voluntad meramente potestativa, caprichosa o insensata" ${ }^{50}$ Luego, al aplicar éste estándar al caso concreto, señala que

"no se presentan los presupuestos de procedencia antes referidos, desde que el
solicitante admite en su presentación que durante la investigación se recabaron una
serie de antecedentes testimoniales, periciales y documentales que fundaron la
imputación y que son, además, los usuales en la indagación de delitos como los de
la especie, evidencias que fueron debidamente analizadas por los jueces del juicio
oral y que se estimaron insuficientes a efectos de superar el estándar de duda
razonable, circunstancia que, por sí sola, no tiene la aptitud necesaria para fundar

los argumentos expuestos en el considerando segundo, me parece que se reclama, más bien, de la prisión preventiva decretada en su contra.

${ }^{45}$ En la SCS rol nº11730-2014 sólo se señala en el considerando segundo que el solicitante pide que se "declare que ha sido injustamente privado de libertad..."

${ }^{46}$ SCS rol no $11730-2014$ y n ${ }^{\circ} 9559-2015$.

${ }^{47}$ SCS rol no $11730-2014$.

${ }^{48}$ SCS rol no $9559-2015$.

${ }^{49}$ Considerando segundo, SCS rol no ${ }^{\circ} 9559-2015$.

${ }^{50}$ Considerando tercero SCS rol $\mathrm{n}^{\circ} 11730-2014$ y considerando tercero SCS rol no ${ }^{\circ}$ 9559-2015 (en ambas sentencias aparece el párrafo citado). 


\section{Polít. Crim. Vol. 14, No 28 (Diciembre 2019), Art. 6, pp. 216-268. [http://politcrim.com/wp-content/uploads/2019/12/Vol14N28A6.pdf]}

una pretensión como la de estos antecedentes, motivo por el cual no se dará tramitación a la solicitud". ${ }^{1}$

En el tercer caso, ${ }^{52}$ se reclama respecto de una resolución que decreta prisión preventiva por no pago de la multa impuesta como condena y que, sin embargo, se encontraba debidamente cancelada. Por ello, afirma haber sido "injustamente privado de libertad". Ante esta alegación, la Corte Suprema establece la misma definición de resolución “injustificadamente errónea o arbitraria” indicada más arriba y pasa a aplicarla al caso concreto señalando que "el solicitante admite en su presentación que fue condenado y que incluso dio cumplimiento a la sanción que le fuera impuesta, por lo que la inadvertencia al disponer su detención para el solo efecto de su cumplimiento, por sí sola, no tiene la aptitud necesaria para fundar una pretensión como la de estos antecedentes". 53

Considerando todo lo señalado hasta aquí, pareciera que las inadmisibilidades no representan un obstáculo significativo para el ejercicio del derecho a indemnización por error judicial o, al menos, no es un impedimento que esté generando la Corte Suprema. En definitiva, si comparamos el comportamiento de la Corte analizado en este trabajo con el gran obstáculo que representa esta fase en otro tipo de recursos, llegaremos a la conclusión de que no estamos en presencia de una barrera significativa. En efecto, si comparamos por ejemplo con el recurso de revisión, podremos observar que en el período 2007 a 2016 la Corte desechó el $87,84 \%$ de los recursos "de plano"54 y si lo hacemos con el recurso de nulidad presentado por la causal del artículo 373 letra a) del CPP en el período 2001 a 2013 la Corte declaró inadmisible el $72 \%$ de los recursos. ${ }^{55}$ En este contexto, no podemos afirmar que las inadmisibilidades que se han decretado en los 12 años comprendidas en este estudio sean propiamente un impedimento para el ejercicio del derecho a la indemnización por error judicial, mucho menos si se analiza con detalle el motivo de estas resoluciones, como se ha hecho en la presente sección.

\section{Resoluciones que rechazan la solicitud con argumentos de fondo}

El propósito de la presente sección es analizar los distintos argumentos utilizadas por la Corte para rechazar por consideraciones de fondo 46 de las 66 solicitudes. Para ello, describiremos, en primer lugar, los distintos argumentos que se utilizan y la frecuencia con que lo hacen, con lo que se podrá identificar específicamente cuáles son las barreras para los solicitantes una vez que han superado la etapa de admisibilidad. Posteriormente, profundizaremos en lo que la Corte entiende por resolución "injustificadamente errónea o arbitraria", describiendo las distintas definiciones que ha utilizado en este período para dichos conceptos y el razonamiento que la lleva a concluir que una resolución no tiene estas características.

\footnotetext{
${ }^{51}$ Considerando cuarto SCS rol $\mathrm{n}^{\circ}$ 9559-2015 y considerando cuarto SCS rol $\mathrm{n}^{\circ} 11486-2017$ (en ambas sentencias aparece el párrafo citado).

${ }_{53}^{52}$ SCS rol nº19263-2017.

${ }^{53}$ La definición mencionada se encuentra en el considerando tercero de la SCS rol nº19263-2017 y el párrafo citado en el considerando cuarto.

${ }^{54}$ DUCE, "Los recursos de revisión", cit. nota n ${ }^{\circ}$, pp. 10-11.

${ }^{55}$ CENTRO DE ESTUDIOS DE LA JUSTICIA, El recurso de nulidad en materia penal: jurisprudencia de la Corte Suprema años 2001-2013, Santiago: Facultad de Derecho Universidad de Chile, 2015, p. 24.
} 
DUCE, Mauricio; VILLARROEL, Romina, "Indemnización por error judicial: una aproximación empírica a la jurisprudencia de la Corte Suprema de los años 2006-2017”

\subsection{Argumentos utilizados por la Corte para rechazar las solicitudes: visión general}

Un primer hallazgo de la investigación muestra que la principal razón para rechazar la solicitud es, como intuía la doctrina y los proyectos de reforma constitucional, el estándar de resolución "injustificadamente errónea o arbitraria”. En efecto, en 33 de las 46 solicitudes rechazadas $(71,7 \%$ de 46$)$ la Corte Suprema utilizó como único argumento para llegar a esta decisión el hecho de que la resolución impugnada no tenía este carácter. ${ }^{56}$

Por otro lado, en cuatro casos más ${ }^{57}$ (8,7\% de 46) la Corte utilizó este argumento en forma secundaria. Es decir, a pesar que la Corte considera que no se cumplen las exigencias reguladas en el artículo $19 \mathrm{n}^{\circ} 7$ letra i) ya que no se trata de resoluciones impugnables (en todas ellas no hubo auto de procesamiento ni condena o sobreseimiento definitivo) y, por ese sólo hecho podía rechazar las solicitudes de declaración previa, igualmente se hace cargo en todos los casos de consideraciones de fondo para arribar a la misma decisión, señalando que no podría afirmarse la existencia de un error injustificado o de arbitrariedad en las resoluciones impugnadas.

Finalmente, en cinco casos más ${ }^{58}(10,9 \%$ de 46$)$ la Corte rechaza la solicitud porque la resolución impugnada no es injustificadamente errónea o arbitraria y, de haber responsabilidad, esta correspondería al Ministerio Público. Específicamente, en cuatro de los $\operatorname{casos}^{59}$ en que se condena a una persona inocente debido a un error en la identidad del verdadero imputado, la Corte afirma que, como no se han vulnerado las únicas normas invocadas por el solicitante en relación a la verificación de identidad del imputado, no es posible afirmar que la resolución impugnada deviniera de un error judicial puesto que la responsabilidad en la identificación de los imputados recae en los funcionarios de la policía, sea civil o uniformada, y luego, en el Ministerio Público. Con ello, la Corte descarta la existencia de un error por parte del juez y luego, pasa a afirmar que tal responsabilidad debe reclamarse a través del artículo $5^{\circ}$ de la Ley Orgánica Constitucional del Ministerio Público (en adelante LOCMP), norma no requiere una declaración previa de la Corte. En el otro caso, en que también se produce un error en la identidad del imputado, pero esta vez en el contexto de un procedimiento monitorio, la Corte afirma en su considerando noveno que:

"la resolución que aprobó el procedimiento monitorio no participa de las características de "injustificadamente errónea y arbitraria" pero agrega en el considerando undécimo que "si la acción impetrada pretende reprochar actuaciones del Ministerio Público, ya no se trata de un error judicial. Para este evento el artículo

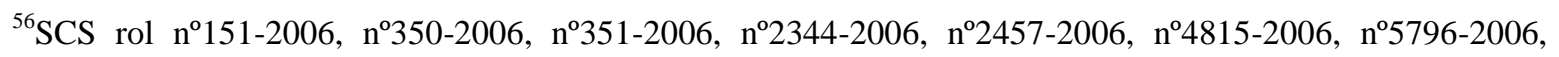
$\mathrm{n}^{\mathrm{o}} 408-2007, \mathrm{n}^{\mathrm{o}} 6190-2007, \mathrm{n}^{\circ} 498-2008, \mathrm{n}^{\circ} 1386-2008, \mathrm{n}^{\circ} 3450-2008, \mathrm{n}^{\circ} 4357-2008, \mathrm{n}^{\circ} 1678-2009, \mathrm{n}^{\circ} 5742-2009$, $n^{\circ} 398-2010, n^{\circ} 2709-2010, n^{\circ} 2751-2010, n^{\circ} 2804-2010, n^{\circ} 5269-2011, n^{\circ} 1238-2012, n^{\circ} 7279-2012, n^{\circ} 7937-$

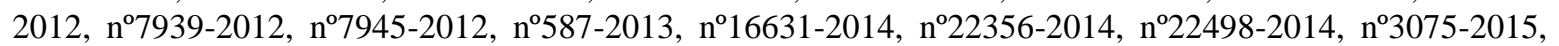
n⿳0十0829-2016, nº33813-2017 y n $83373-2016$.

${ }^{57}$ SCS rol nº3815-2006, $\mathrm{n}^{\circ} 3030-2007, \mathrm{n}^{\circ} 5572-2007$ y n $5270-2008$.

${ }^{58}$ SCS rol n ${ }^{\circ} 2640-2008, n^{\circ} 7854-2008, n^{\circ} 7720-2010, n^{\circ} 7837-2010$ y nº44998-2016.

${ }^{59}$ SCS rol no2640-2008, no $7854-2008, n^{\circ} 7720-2010$ y n ${ }^{\circ} 7837-2010$.
} 


\section{Polít. Crim. Vol. 14, No 28 (Diciembre 2019), Art. 6, pp. 216-268. [http://politcrim.com/wp-content/uploads/2019/12/Vol14N28A6.pdf]}

$5^{\circ}$ de la Ley Orgánica Constitucional del Ministerio Público contempla la responsabilidad de dicho ente público ante los ciudadanos". 60

En suma, además de los 33 casos en que la Corte rechaza la solicitud con el único argumento de que la resolución no es "injustificadamente errónea o arbitraria", existen otras nueve ocasiones en que también usa este argumento, pero en complemento con otro. De esta manera, en 42 casos (91,3\% de 46) ha sido una barrera lo que la Corte entiende por "resolución injustificadamente errónea o arbitraria".

Con respecto a los cuatro casos restantes, en $\operatorname{dos}^{61}$ de ellos la Corte rechazó la solicitud por no impugnar una sentencia condenatoria o un auto de procesamiento sino una resolución sobre medidas cautelares. En estos casos, la Corte se limita a señalar que la norma autoriza la declaración en cuestión sólo respecto de sentencias condenatorias y autos de procesamiento y luego descarta que la resolución sobre cautelares sea una u otra. A diferencia de los casos descritos anteriormente, utiliza sólo este argumento para rechazar, sin usar, además, el argumento de fondo en cuanto a que las resoluciones impugnadas tampoco serían injustificadamente erróneas o arbitrarias. De esta manera, si sumamos los cuatro $\operatorname{casos}^{62}$ ya mencionados en que la Corte utilizó este argumento en conjunto con descartar que la resolución es injustificadamente errónea o arbitraria, podemos concluir que el hecho de que la Corte considere que la resolución sobre medidas cautelares no queda comprendida por la norma constitucional, ha sido una barrera en seis de 46 casos en el período estudiado (13\%). Como ya hemos señalado en una sección previa, este criterio habría cambiado a partir del año 2015, es decir, en la parte final del período cubierto por nuestra investigación.

Por otro lado, en un caso ${ }^{63}$ la Corte señala que "la acción formalizada no puede prosperar, al no acompañar el peticionario los antecedentes mínimos que eran de su cargo, para emitir un pronunciamiento estimatorio de lo solicitado". ${ }^{64}$ Específicamente, en este caso la Corte Suprema señala que el solicitante

"sólo agregó a este legajo copias de las actas de las audiencias en que pronuncian las resoluciones objetadas, las cuales no contienen una transcripción, extracto o resumen de las alegaciones y antecedentes expuestos por el Ministerio Público y la defensa en cada una de ellas, ni tampoco de las razones entregadas por el Tribunal en cada oportunidad para decretar o mantener la prisión preventiva -salvo en el acta de la audiencia de 16 de octubre de 2009-. Tal defecto impide emitir un pronunciamiento sobre el mérito de las resoluciones objetadas, pues en un sistema de estructura acusatoria como el diseñado por el Código Procesal Penal, tales dictámenes jurisdiccionales no son sino el resultado del debate sostenido en cada audiencia por el Ministerio Público y la defensa". ${ }^{65}$

\footnotetext{
${ }^{60} \mathrm{SCS}$ rol n44998-2016, considerando $9^{\circ}$.

${ }^{61}$ SCS rol n4463-2010 y n⿳ 8462-2010.

${ }^{62}$ SCS rol n³815-2006, n³030-2007, n5572-2007 y n5270-2008.

${ }^{63}$ SCS rol n⿳4021-2014.

${ }^{64} \mathrm{SCS}$ rol n $\mathrm{n}^{\circ} 4921-2014$ considerando $14^{\circ}$.

${ }^{65} \mathrm{SCS}$ rol n ${ }^{\circ} 4921-2014$ considerando $10^{\circ}$.
} 
En otro considerando, la Corte reprocha al solicitante no haber acompañado copia de antecedentes que respalden sus argumentos, específicamente, de aquellos que, según él, el Juzgado de Garantía habría desatendido al dictar las resoluciones (copia de la carpeta investigativa y declaraciones de testigos que configuraban su "coartada"), puesto que, sin ellos, no es posible efectuar un reproche al desempeño del Tribunal.

Finalmente, en el caso restante ${ }^{66}$ la Corte rechaza la solicitud de declaración previa a la indemnización por error judicial por extemporánea y, luego, rechaza la petición subsidiaria del solicitante de que "se declare el error judicial sobre la base de las actuaciones erróneas del Ministerio Público, de conformidad con lo que al efecto disponen los artículos $4^{\circ}$ de la Ley Orgánica Constitucional de Bases Generales de la Administración del Estado, $5^{\circ}$ de la Ley Orgánica Constitucional del Ministerio Público y $19 \mathrm{~N}^{\circ} 7$ letra i) de la Carta Fundamental". ${ }^{67}$ Específicamente, la Corte responde que

"si la acción se deduce subsidiariamente por las actuaciones que se reprochan al Ministerio Público, ya no se trata de un error judicial. Para este evento el artículo $5^{\circ}$ de la Ley Orgánica Constitucional del Ministerio Público contempla la responsabilidad de dicho ente público... Se trata de una hipótesis de responsabilidad administrativa del Estado, no jurisdiccional, que naturalmente no puede generar esta última clase de responsabilidad, merced a que es la actividad de una entidad autónoma impedida de ejercer labores jurisdiccionales, como expresamente dispone el artículo $1^{\circ}$ de su Ley Orgánica. Por consiguiente, la acción para obtener la reparación del Estado por una actuación de tal peculiaridad del Ministerio Público es de responsabilidad administrativa del Estado y, como tal, debe ejercerse del mismo modo que todas aquellas que son contencioso administrativas y que no tienen designado un procedimiento especial", ${ }^{6}$

Los resultados expuestos en esta parte se resumen en la tabla $\mathrm{n}^{\circ} 9$.

Tabla $\mathrm{n}^{\circ}$ 9:

Argumentos utilizados por la Corte para rechazar, años 2006-2017

Fuente: Elaboración propia

\begin{tabular}{|l|c|}
\hline \multicolumn{1}{|c|}{ Argumento } & $\mathbf{N}^{\circ} \mathbf{y} \%$ \\
\hline Injustificadamente errónea o arbitraria (principal) & $33(71,7 \%)$ \\
\hline Injustificadamente errónea o arbitraria (secundaria) & $4(8,7 \%)$ \\
\hline Injustificadamente errónea o arbitraria (Ministerio Público) & $5(10,9 \%)$ \\
\hline No resolución recurrible (medidas cautelares) & $2(4,3 \%)$ \\
\hline Otros & $2(4,3 \%)$ \\
\hline Total & $\mathbf{4 6 ( 1 0 0 \% )}$ \\
\hline
\end{tabular}

En lo que sigue analizaremos con más detención los casos en que la Corte estima que no está en presencia de una resolución injustificadamente errónea o arbitraria debido a que se

\footnotetext{
${ }^{66}$ SCS rol nº1465-2011.

${ }^{67}$ SCS rol n ${ }^{\circ} 1465-2011$ considerando $1^{\circ}$.

${ }^{68} \mathrm{SCS}$ rol no $1465-2011$ considerando $7^{\circ}$.
} 


\section{Polít. Crim. Vol. 14, No 28 (Diciembre 2019), Art. 6, pp. 216-268. [http://politcrim.com/wp-content/uploads/2019/12/Vol14N28A6.pdf]}

trata por lejos de la causal principal invocada por la Corte Suprema para el rechazo de estas solicitudes según hemos visto.

\section{2. ¿Cuándo la resolución no es injustificadamente errónea o arbitraria según la Corte Suprema?}

A lo largo del período en estudio, la Corte frecuentemente ha ofrecido definiciones de los conceptos para explicar cuando una resolución es "injustificadamente errónea" y "arbitraria" $\mathrm{y}$, también, ha registrado diversos argumentos para no subsumir las resoluciones impugnadas en dichas definiciones. Estas definiciones y argumentos serán estudiadas a continuación. Antes de abordar esto, es necesario aclarar que en 23 ocasiones ${ }^{69}$ la Corte no ha sido tan precisa, y ha ofrecido una sola definición para la resolución "injustificadamente errónea o arbitraria", de manera que convierte ambos conceptos en una sola hipótesis o, aun cuando los define por separado, entrega argumentos conjuntos para descartar la existencia de un error injustificado y la arbitrariedad, a la vez. Con el fin de aislar adecuadamente las definiciones separadas de ambos conceptos, así como los argumentos para descartar su presencia, el razonamiento de la Corte en estos casos "imprecisos" será revisado en forma separada.

\subsubsection{Resolución injustificadamente errónea}

En la primera de resolución del período, ${ }^{70}$ la Corte Suprema aclara que no basta con la verificación de un error en la resolución impugnada, sino que debe tratarse de un error "injustificado". En este sentido, señala:

"No es suficiente con que haya sido "errónea", o sea, equivocada, inexacta, desacertada o continente de un juicio falso, sino que es indispensable que tal error sea "injustificado". Ello es así, ya que la actividad de juzgar, como cualquier otra realizada por el ser humano, está expuesta a incurrir en equivocaciones o desaciertos, los cuales son explicables precisamente a causa de las limitaciones inherentes a la naturaleza del hombre, de cuyas virtudes y defectos participan, como es obvio, también los jueces". ${ }^{71}$

En otras sentencias, la Corte recurre a la Real Academia Española para delimitar el significado de "injustificado". Así, sostiene

"injustificado es lo "no justificado" (Diccionario de la Lengua Española, 21 Edición), por lo que se debe delimitar lo que se ha de entender por "justificado"; arroja un poco de luz sobre el significado del antónimo, señalando que es lo "conforme a justicia y razón"; a su turno, explica que "justificación", en su tercera

\footnotetext{
${ }^{69}$ SCS rol no $2344-2006, n^{\circ} 2457-2006, n^{\circ} 4815-2006, n^{\circ} 3030-2007, n^{\circ} 1386-2008, n^{\circ} 4357-2008, n^{\circ} 5270-2008$, $\mathrm{n}^{\circ} 1678-2009, \mathrm{n}^{\circ} 5742-2009, \mathrm{n}^{\circ} 398-2010, \mathrm{n}^{\circ} 2709-2010, \mathrm{n}^{\circ} 2751-2010, \mathrm{n}^{\circ} 2804-2010, \mathrm{n}^{\circ} 7720-2010, \mathrm{n}^{\circ} 5269-$ 2011, n ${ }^{\circ} 1238-2012, \mathrm{n}^{\circ} 22498-2014, \mathrm{n}^{\circ} 25658-2014, \mathrm{n}^{\circ} 1579-2015, \mathrm{n}^{\circ} 3075-2015, \mathrm{n}^{\circ} 44998-2016, \mathrm{n}^{\circ} 83373-2016$ y $\mathrm{n}^{\circ} 11486-2017$.

${ }^{70}$ SCS rol nº151-2006.

${ }^{71}$ SCS rol n ${ }^{\circ} 151-2006$ considerando $7^{\circ}$. También se repite este párrafo en SCS rol nº350-2006 considerando $9^{\circ}, n^{\circ} 351-2006$ considerando $9^{\circ}, n^{\circ} 3815-2006$ considerando $6^{\circ}, n^{\circ} 408-2007$ considerando $8^{\circ}, n^{\circ} 5572-2007$ considerando $11^{\circ} \mathrm{y} \mathrm{n}^{\circ} 5411-2010$ considerando $1^{\circ}$.
} 
acepción, quiere decir "prueba convincente de una cosa", agregando luego en el mismo sentido que "justificar", en su segunda significación, supone "probar una cosa con razones convincentes, testigos o documentos". 72

Ante esta definición, la Corte concluye en estas mismas sentencias que "una resolución o sentencia es injustificadamente errónea, cuando los razonamientos que la conducen al resultado inexacto no convencen (no son convincentes), cuando no son susceptibles de una explicación razonable (racional) cuando, en fin, son contrarios a la lógica, a los dictados de la experiencia y a los conocimientos más difundidos sobre la materia respecto a la cual versa".

Esta definición entregada por la Corte, fue reproducida textualmente en otras 12 resoluciones que rechazan la solicitud intentada ${ }^{73}$ y fue la utilizada en la primera de las resoluciones que acogen la solicitud de declaración previa. ${ }^{74}$ Además, es posible advertir que esta definición viene desde antes del período en estudio, puesto que como relata el Carmona, fue utilizada el 2002 en el caso "Eva Sánchez". 75

Adicionalmente, en algunas resoluciones la Corte se pronuncia sobre la magnitud del error en cuestión, aludiendo a la historia fidedigna del establecimiento de la norma. De esta forma, señala: “...de acuerdo a lo expresado por la Comisión Constituyente en la sesión 119, el error judicial debe ser manifiesto, craso, que es el que no admite excusa ni razón para explicarlo...".76

Estas son las únicas dos definiciones que la Corte ha utilizado expresamente para el concepto resolución "injustificadamente errónea". En el resto de los casos, la Corte mezcla los conceptos resolución "injustificadamente errónea" y resolución "arbitraria" definiéndolos conjuntamente. Como ya señalamos, estos casos serán estudiados más adelante.

Hasta aquí, es posible resumir el entendimiento de la Corte sobre el concepto, en dos ideas. En primer lugar, una resolución es injustificadamente errónea cuando, teniendo argumentos que respaldan la decisión equivocada, estos adolecen de algún tipo de vicio. Específicamente, la Corte alude a tres tipos de defectos en los razonamientos de una resolución: no ser "convincentes", no ser "racionales" (o contradecir la razón) y, finalmente, ser "contrarios a la lógica, a los dictados de la experiencia y a los conocimientos más difundidos sobre la materia respecto a la cual versa”. Como puede apreciarse, estos defectos se orientan a una misma idea, sin embargo, tienen diferencias sutiles. Por ejemplo, un argumento puede ser racional pero no convincente, o estimarse irracional por motivos que no tienen que ver con la lógica, dictados de la experiencia o materia sobre la cual versa. Lo relevante parece ser que, a pesar de tener "elementos de

\footnotetext{
${ }^{72}$ SCS rol n ${ }^{\circ} 5796-2006$ considerando $10^{\circ}$ y n ${ }^{\circ} 3450-2008$ considerando $7^{\circ}$.

${ }^{73}$ SCS rol n³50-2006 y rol n³51-2006, n³815-2006, n5796-2006, nº 408-2007, n5572-2007, n³450-2008, n³98-2010, n²709-2010, n² 2751-2010, n²804-2010 y nº5269-2011.

${ }^{74}$ SCS rol n'5411-2010.

${ }^{75}$ CARMONA, "La responsabilidad del Estado-juez", cit. nota nº12, p. 339. SCS rol nº4576-2002.

${ }^{76}$ SCS rol n³815-2006 considerando $11^{\circ}$ y n³3813-2017 considerando $7^{\circ}$.
} 


\section{Polít. Crim. Vol. 14, No 28 (Diciembre 2019), Art. 6, pp. 216-268. [http://politcrim.com/wp-content/uploads/2019/12/Vol14N28A6.pdf]}

convicción" en que se basa la decisión adoptada, éstos, en realidad, no permiten arribar a dicha conclusión. En segundo lugar, la Corte estima que una resolución es injustificadamente errónea cuando el error cometido tiene cierta magnitud, que señala como "error craso", "que no admite excusa ni razón para explicarlo".

En concordancia con los razonamientos descritos anteriormente, la Corte deja abierta la posibilidad de que exista un error en las resoluciones impugnadas, el que habría quedado de manifiesto cuando una sentencia absolutoria de primera o segunda instancia contradice la decisión recurrida. En este sentido, la Corte concentra sus argumentos en descartar que dicho error haya sido injustificado, señalando que no lo es cuando se cumplen los requisitos que impone la ley a la resolución en cuestión y, en la medida en que estos requisitos también lo exigen, cuando existen antecedentes o pruebas que respaldan la decisión.

En esta dirección, la Corte estima en tres sentencias ${ }^{77}$ que un auto de procesamiento no es injustificadamente erróneo cuando existen múltiples antecedentes que (1) justifican la existencia del delito y (2) permiten presumir fundadamente que el inculpado ha tenido participación en el delito como autor, cómplice o encubridor (requisitos que impone el artículo 274 del Código de Procedimiento Penal). También, la Corte señala en otras tres ocasiones ${ }^{78}$ que una sentencia condenatoria no es injustificadamente errónea si la decisión de los jueces se ajusta al mérito del proceso, es decir, se ha fundado sobre la base de las pruebas suministradas, la que debe haber sido ponderada libremente, como lo señala el CPP.

Lamentablemente, en las ocho resoluciones restantes en que la Corte ofreció un concepto independiente de resolución "injustificadamente errónea", ofrece posteriormente un mismo argumento para descartar también la existencia de una resolución "arbitraria", por lo que serán estudiadas más adelante. Hasta aquí, sin embargo, es posible apreciar que, a pesar de que la Corte define una resolución "injustificadamente errónea" como ya hemos visto, tiende a descartar la existencia de un error injustificado sin analizar si se verifican estos "vicios" en dichos razonamientos, bastándole con que existan antecedentes que respaldan la decisión. En concreto, la Corte menciona los distintos antecedentes o medios de prueba que se tuvieron en cuenta para resolver de esa manera, sin analizar el contenido de éstos, por lo que difícilmente podría estudiar si eran convincentes o permitían concluir razonable o lógicamente lo que decidió el tribunal. De esta manera, parece ser que es tarea del solicitante acreditar que dichos antecedentes no son convincentes, razonables, concordantes con la lógica, etc.

Sólo para ejemplificar este punto, exponemos un caso ${ }^{79}$ en el que la Corte descarta que el auto de procesamiento impugnado sea injustificadamente erróneo o arbitrario, puesto que había múltiples antecedentes que lo respaldaban. Así, señala que "del análisis de la interlocutoria en estudio, se desprende que el señor Ministro Instructor, al dictar el auto de procesamiento tuvo múltiples noticias, consistentes en querellas, partes policiales, declaraciones y oficios, que le permitieron arribar a la convicción que se encontraba

\footnotetext{
${ }^{77}$ SCS rol nº151-2006, nº5796-2006 y nº408-2007.

${ }^{78}$ SCS rol n³50-2006, n³51-2006 y nº408-2007.

${ }^{79}$ SCS rol no151-2006.
} 
DUCE, Mauricio; VILLARROEL, Romina, "Indemnización por error judicial: una aproximación empírica a la jurisprudencia de la Corte Suprema de los años 2006-2017”

acreditado en autos...(los hechos constitutivos de delito que describe el auto de procesamiento)". ${ }^{80}$ Luego la Corte concluye

" $14^{\circ}$ Que, en conclusión, el Ministro señor Solís, para dictar la resolución, contaba con los dichos del imputado de fojas 344, 845 y 918, previa determinación la existencia de un delito, y le atribuyó una participación de cómplice en los hechos a Guzmán del Río, con las presunciones que detalla, cumpliendo con los requisitos del artículo... $17^{\circ}$ Que, en otras palabras, se puede decir con propiedad que la apreciación de los hechos y participación atribuida, en esa etapa procesal, por parte del Ministro señor Solís, al reclamante de autos Raúl Estatiro Guzmán del Río, era ajustada al mérito del proceso. $18^{\circ}$ Que, por lo dicho, la resolución impugnada no fue injustificadamente errónea, como lo pretende el libelo de fojas 131 y siguientes, sino que se trata de un auto de procesamiento dictado cumpliendo las exigencias del artículo 274 del Código de Procedimiento Penal. 19 Que, por lo mismo, tampoco puede apreciarse que haya sido arbitraria...." 81

Como puede apreciarse, lo decisivo para descartar la existencia de una resolución injustificadamente errónea o arbitraria es la disponibilidad de antecedentes que respalden la decisión.

En otro ejemplo, pero de un caso en que se impugna una sentencia definitiva ante un Tribunal Oral en lo Penal, la Corte señala:

"...lo que han decidido en aquella oportunidad no fue un capricho irracional o no fundamentado que tuviera origen a una irracionalidad, sino que un cúmulo de argumentos y probanzas de las más variadas que fueron proporcionadas por todas las partes, y así se puede apreciar de la simple lectura de sus fundamentos. En efecto, en los basamentos sexto, séptimo y octavo expusieron latamente toda la prueba que fue rendida en autos, por todos los intervinientes, reseñándose en ellos la testimonial, documental, objetos aportados; en el motivo noveno, determinaron los hechos y con cuales elementos fueron acreditados, dándoles la calificación jurídica -no discutida, por cierto- en el siguiente. Continúa el fallo en los basamentos siguientes, undécimo y duodécimo señala los motivos que los han llevado a establecer la participación de los imputados. DÉCIMO TERCERO: Que, por consiguiente, no tienen asidero las imputaciones efectuadas por el actor en orden a que la sentencia habría sido injustificadamente errónea, ya que evidentemente, los jueces fundaron su decisión sobre la base de las pruebas suministradas, que fue ponderada libremente, tal como lo ordena el Código Procesal Penal; y al tener los motivos y consideraciones por las cuales han decidido de una determinada manera, se excluye el elemento de arbitrariedad" (las cursivas son nuestras). ${ }^{82}$

\subsubsection{Resolución arbitraria}

En la primera resolución del período, ${ }^{83}$ la Corte Suprema señala que arbitrario es "aquello contrario a la justicia, la razón o las leyes, vale decir, cuando se lo ha dictado obedeciendo

\footnotetext{
${ }^{80} \mathrm{SCS}$ rol n ${ }^{\circ} 151-2006$ considerando $10^{\circ}$ (la información entre paréntesis es un agregado nuestro).

${ }^{81} \mathrm{SCS}$ rol n ${ }^{\circ} 151-2006$ considerandos $14^{\circ}, 17^{\circ}-19^{\circ}$.

${ }^{82} \mathrm{SCS}$ rol n $350-2006$ considerandos $12^{\circ}$ y $13^{\circ}$.

${ }^{83}$ SCS rol nº151-2006.
} 


\section{Polít. Crim. Vol. 14, No 28 (Diciembre 2019), Art. 6, pp. 216-268. [http://politcrim.com/wp-content/uploads/2019/12/Vol14N28A6.pdf]}

sólo a la voluntad o al capricho". ${ }^{84}$ Es decir, la Corte mantiene exactamente la misma definición acordada en la historia fidedigna del establecimiento de la norma ${ }^{85}$ que a su vez fue tomada directamente del Diccionario de la Real Academia Española y que, como describe la doctrina, ha sido utilizada en sentencias anteriores al período en estudio de este trabajo. ${ }^{86}$ Esta definición se repite textualmente en seis sentencias posteriores ${ }^{87}$ agregando en algunos casos, frases como "o que carezca de motivación o racionalidad". 88

Lamentablemente, estas son las únicas resoluciones en que la Corte define aisladamente el concepto de "resolución arbitraria". En los demás casos, la Corte ofrece una definición y razonamiento conjunto para la frase resolución "injustificadamente errónea o arbitraria", mientras que, en otros, ${ }^{89}$ a pesar de definir aisladamente "injustificadamente errónea" no define "arbitraria".

En cuanto a su aplicación, ni una resolución que se pronuncia en la materia entrega argumentos "nuevos" para descartar la arbitrariedad. En efecto, en dos resoluciones ${ }^{90}$ la Corte descarta que exista una resolución injustificadamente errónea porque los autos procesamiento y sentencia condenatoria impugnados estaban fundados en múltiples antecedentes que justificaban la existencia del delito y permitían presumir fundadamente la participación del inculpado, y luego señala: "Que, por lo mismo, tampoco puede apreciarse que haya sido "arbitraria". Pues arbitrario es aquello "contrario a la justicia, la razón o las leyes", vale decir, cuando se lo ha dictado obedeciendo sólo a "la voluntad o al capricho", y todo lo expuesto antes demuestra que no es el caso". ${ }^{91}$

Por otro lado, existen tres casos ${ }^{92}$ en que, a pesar de ofrecer una definición independiente para cada hipótesis, la Corte argumenta conjuntamente por qué no se trata de una resolución "injustificadamente errónea o arbitraria", haciendo inútil las definiciones independientes que antes habíamos dado. Estos argumentos serán analizados más adelante. En otros casos, en cambio, los argumentos son independientes para cada concepto. En dos resoluciones ${ }^{93}$ la Corte estima que la sentencia condenatoria no es arbitraria, por contener explícitamente los argumentos que la llevaron a condenar. Así, la Corte señala: "y al tener los motivos y consideraciones por las cuales han decidido de una determinada manera, se excluye el elemento de arbitrariedad". ${ }^{94}$ Destaca, en este sentido, el argumento que da antes de arribar a esta conclusión, en que señala: "los jueces al resolver en la forma como lo hicieron han escuchado a todas las partes intervinientes, y han fundamentado su decisión,

\footnotetext{
${ }^{84} \mathrm{SCS}$ rol n ${ }^{\circ} 151-2006$ considerando $19^{\circ}$.

${ }^{85}$ Señor Ortúzar, Sesión 119a, celebrada en jueves 8 mayo de 1975. Una reproducción del acta puede verse en EVANS, Los derechos, cit. nota ${ }^{\circ} 14$, pp. 90-94.

${ }^{86}$ CARMONA, "La responsabilidad del Estado-juez", cit. nota $\mathrm{n}^{\circ} 12$, p. 341.

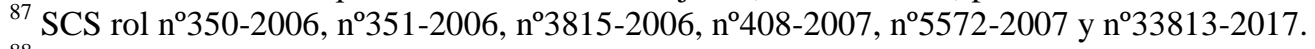

${ }^{88} \mathrm{SCS}$ rol no $5572-2007$ y n⿳033813-2017.

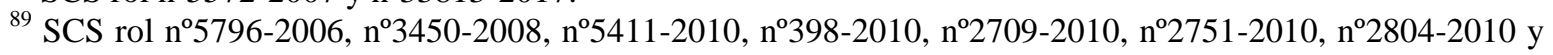
nº5269-2011.

${ }^{90} \mathrm{SCS}$ rol n $151-2006$ y n $^{\circ} 408-2007$.

${ }^{91} \mathrm{SCS}$ rol ${ }^{\circ} 151-2006$ considerando $19^{\circ}$ y $\mathrm{n}^{\circ} 408-2007$ considerando $12^{\circ}$.

${ }^{92}$ SCS rol n⿳3815-2006, $\mathrm{n}^{\circ} 5572-2007$ y n³3813-2017.

${ }^{93} \mathrm{SCS}$ rol n⿳0 $350-2006$ y n $351-2006$.

${ }^{94} \mathrm{SCS}$ rol no350-2006 considerando $13^{\circ}$ y n ${ }^{\circ} 351-2006$ considerando $13^{\circ}$.
} 
de manera acertada o no, pero se han hecho cargo de la prueba rendida, señalando los medios que les han servido de convicción para resolver tal como lo hicieron, tanto en el establecimiento del delito, como en la determinación de la participación". ${ }^{95}$ De esta manera, la Corte deja abierta la posibilidad de que la decisión no haya sido la correcta, sin embargo, descarta que sea arbitraria la medida en que está debidamente fundamentada y se hace cargo de la prueba rendida en la forma en que lo ordena el CPP.

Nos parece que el estándar impuesto por la Corte para descartar la arbitrariedad es sumamente bajo, puesto que simplemente exige fundamentación de la sentencia, lo que coincide con los contenidos mínimos que debe tener una sentencia definitiva y una resolución sobre cautelares según los artículos 143, 342 y 297 del CPP. Con todo, no es posible afirmar que este razonamiento constituya una jurisprudencia uniforme de la Corte, puesto que, del universo total de casos, sólo en dos de ellos se pronuncia específicamente sobre la arbitrariedad, dando una definición y una argumentación independientes para este concepto. Por lo tanto, contamos con pocas pistas de lo que entiende la Corte Suprema por "resolución arbitraria". Al parecer, la tendencia de la Corte es concentrar sus fundamentos en descartar la existencia de una resolución "injustificadamente errónea" o, derechamente, de absorber en este concepto al de arbitrariedad.

Como última cuestión nos interesa mencionar que existen dos sentencias ${ }^{96}$ en que la Corte estima que la exigencia de "injustificadamente" no sólo es exigible al error sino también a los casos de resoluciones arbitrarias, lo que eventualmente tendría un impacto en hacer más exigente el estándar. Así, se señala

"cabe destacar que aun cuando la petición en estudio se construye utilizando sólo el
calificativo de "arbitrario", en términos que podría suponerse que la conjunción "o",
que une los dos conceptos, es de carácter disyuntivo, con lo que la pretensión se
limitaría a una de las dos cualidades que fija la ley, desde que la solicitud en estudio
no atribuye, o bien prescinde, de la eventual característica de ser "errónea", es lo
cierto que ello no tiene el referido alcance, desde que la verdadera calificante de
ambos conceptos es el de ser éstos "injustificados", término que corresponde
analizar" (las cursivas son nuestras).

A pesar de esto, no estamos en presencia de un tema que se plantee regularmente en las sentencias estudiadas y que, al parecer, sólo cuenta con un apoyo marginal en la doctrina nacional. $^{98}$

\subsubsection{Resolución injustificadamente errónea o arbitraria}

Como se adelantó, existen múltiples casos en que la Corte define conjuntamente la frase resolución "injustificadamente errónea o arbitraria" o, incluso cuando define estas hipótesis separadamente, utiliza una misma argumentación para descartar la existencia de ambas. A continuación, se analiza el razonamiento de la Corte en estos casos.

\footnotetext{
${ }^{95} \mathrm{SCS}$ rol n⿳30350-2006 considerando $12^{\circ} \mathrm{y} \mathrm{n}^{\mathrm{o}} 351-2006$ considerando $12^{\circ}$.

${ }^{96}$ SCS rol n⿳5 5796-2006 y n⿳3050-2008.

${ }^{97}$ SCS rol n⿳5 5796-2006 considerando $9^{\circ}$ y n ${ }^{\circ} 3450-2008$ considerando $6^{\circ}$.

${ }^{98}$ GARRIDO, “La Indemnización”, cit. nota nº 17, p. 477.
} 


\section{Polít. Crim. Vol. 14, No 28 (Diciembre 2019), Art. 6, pp. 216-268. [http://politcrim.com/wp-content/uploads/2019/12/Vol14N28A6.pdf]}

A lo largo del período en estudio la Corte ha ofrecido diversas definiciones de resolución “injustificadamente errónea o arbitraria". Una de ellas, utilizada en ocho casos, ${ }^{99}$ señala que es aquella que "se dictó sin existir elementos de convicción que permitieran fundarla racionalmente, o se expidió por voluntad meramente potestativa, caprichosa o insensatamente". ${ }^{100}$ Esta definición es casi exactamente la misma que se utiliza para aceptar $\operatorname{tres}^{101}$ de las cuatro solicitudes acogidas del período en estudio, en que la Corte señala que estos adjetivos se aplican a "actuaciones de la judicatura desprovistas de elementos de convicción que habiliten su sustento racional o que fueron expedidas por voluntad meramente potestativa, caprichosa o insensata". ${ }^{102}$ Este último adjetivo también ha sido reemplazado en algunas sentencias por el término "irreflexiva".

Una segunda definición, utilizada en otras siete ${ }^{103}$ ocasiones por la Corte, estima que una resolución injustificadamente errónea o arbitraria es aquella "carente de toda justificación, sin motivo o causa plausible, sin fundamento racional, cometiéndose un error craso". ${ }^{104}$ En algunos casos también se agrega la frase "sin elementos que pudieran haber conducido al juez a la conclusión a la que arribó". ${ }^{10}$

Una última definición es aquella en que la Corte estima que los calificativos "injustificadamente errónea o arbitraria" "sólo pueden aplicarse a una resolución judicial que contradice a la razón, que es inexcusable, que ha sido decretada de manera irregular o caprichosa, que carece de una explicación lógica, de motivación y racionalidad". ${ }^{06}$ Esta definición también ha sido utilizada en ocho sentencias. ${ }^{107}$

En suma, todas estas definiciones apuntan a que una resolución injustificadamente errónea o arbitraria es aquella que carece de fundamentación. Así lo indican las frases "se dictó sin existir elementos de convicción que permitieran fundarla racionalmente", "carente de toda justificación, sin motivo o causa plausible, sin fundamento racional", "sin elementos que pudieran haber conducido al juez a la conclusión a la que arribó", "carece de una

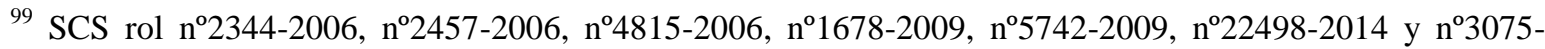
$2015 \mathrm{y} \mathrm{n}^{\circ} 83373-2016$.

${ }^{100}$ SCS rol $\mathrm{n}^{\circ} 2344-2006$ considerando $5^{\circ}, \mathrm{n}^{\circ} 2457-2006$ considerando $5^{\circ}, \mathrm{n}^{\circ} 4815-2006$ considerando $5^{\circ}$, $\mathrm{n}^{\circ} 1678-2009$ considerando $10^{\circ}, \mathrm{n}^{\circ} 5742-2009$ considerando $10^{\circ}, \mathrm{n}^{\circ} 22498-2014$ considerando $6^{\circ}, \mathrm{n}^{\circ} 3075-2015$ considerando $5^{\circ}$ y n ${ }^{\circ} 83373-2016$ considerando $5^{\circ}$.

${ }^{101}$ SCS rol nº $25658-2014, \mathrm{n}^{\circ} 1579-2015$ y n ${ }^{\circ} 11486-2017$.

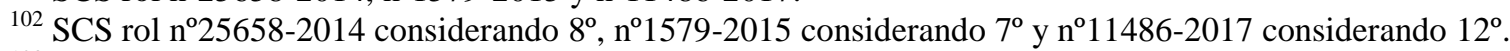

${ }^{103}$ SCS rol n $3030-2007, n^{\circ} 5270-2008, n^{\circ} 398-2010, n^{\circ} 2709-2010, n^{\circ} 2751-2010, n^{\circ} 2804-2010, n^{\circ} 7720-2010$ y $\mathrm{n}^{\circ} 5269-2011$.

${ }^{104}$ SCS rol $\mathrm{n}^{\circ} 3030-2007$ considerando $5^{\circ}, \mathrm{n}^{\circ} 5270-2008$ considerando $14^{\circ}, \mathrm{n}^{\circ} 398-2010$ considerando $5^{\circ}$, $\mathrm{n}^{\circ} 2709-2010$ considerando $5^{\circ}, \mathrm{n}^{\circ} 2751-2010$ considerando $7^{\circ}, \mathrm{n}^{\circ} 2804-2010$ considerando $11^{\circ}$ y n ${ }^{\circ} 5269-2011$ considerando $12^{\circ}$.

${ }_{105}$ SCS rol n ${ }^{\circ} 398-2010$ considerando. $5^{\circ}, n^{\circ} 2709-2010$ considerando $5^{\circ}, n^{\circ} 2751-2010$ considerando $7^{\circ}$, $\mathrm{n}^{\circ} 2804-2010$ considerando $11^{\circ}$ y n $^{\circ} 5269-2011$ considerando $12^{\circ}$.

${ }^{106}$ SCS rol n ${ }^{\circ} 1386-2008$ considerando $9^{\circ}, \mathrm{n}^{\circ}$ 4357-2008 considerando $10^{\circ}, \mathrm{n}^{\circ} 2709-2010$ considerando $6^{\circ}$, $\mathrm{n}^{\circ} 2751-2010$ considerando $8^{\circ}, \mathrm{n}^{\circ} 2804-2010$ considerando $12^{\circ}, \mathrm{n}^{\circ} 1238-2012$ considerando $5^{\circ}, 44998-2016$ considerando $4^{\circ}$ y n ${ }^{\circ} 83373-2016$ considerando $6^{\circ}$.

${ }^{107}$ SCS rol nº $1386-2008, n^{\circ} 4357-2008, n^{\circ} 2709-2010, n^{\circ} 2751-2010, n^{\circ} 2804-2010, n^{\circ} 1238-2012,44998-2016$ y no $83373-2016$.
} 
explicación lógica, de motivación y racionalidad". Por estas razones, la resolución infundada también podría calificarse como decretada "de manera irregular o caprichosa" y "por voluntad meramente potestativa, caprichosa o insensatamente".

De esta manera, se difumina completamente la diferencia entre ambas hipótesis, puesto que la Corte, con estas ideas, se inclina por lo que comúnmente podríamos llamar "arbitrariedad" y no un "error". En este sentido, llama la atención que, como hemos visto anteriormente, la Corte concentre sus esfuerzos argumentativos en el concepto de "error injustificado" cuando sus argumentos para descartarlo son, principalmente, la falta de fundamento de la decisión.

Al aplicar estas definiciones a los casos concretos, el comportamiento de la Corte es coherente con lo descrito y descarta la existencia de una resolución injustificadamente errónea o arbitraria cuando existen antecedentes o medios probatorios que permiten respaldar la decisión tomada. Por ejemplo, la Corte descarta que la resolución que decreta prisión preventiva haya sido injustificadamente errónea o arbitraria señalando que el Ministerio Público tenía varios antecedentes que la defensa no logró desvirtuar. ${ }^{108}$ También, la Corte descarta estas hipótesis, no basándose en los antecedentes que presenta el fiscal, sino en la valoración que hace en tribunal de ellos. En este sentido señala:

\begin{abstract}
"Que, en consecuencia, contrariamente a lo que se expresa en el libelo de autos, la sentencia cuestionada contiene una exposición de las probanzas y un desarrollo claro y lógico que permite comprender cómo se llega a las conclusiones que se indican y a los hechos que se dan por establecidos así como las reglas de la debida dictación y fundamentación de un fallo sin perjuicio de la diferente opinión referida a las reglas de valoración de los medios de prueba que permiten dar por establecidos ciertos sucesos...Que en dicho contexto, la sentencia cuestionada -contrario a lo sostenido por el recurrente-, explicó, como en derecho correspondía, los argumentos que la condujeron a adoptar su decisión de condena, en particular al quedar refrendado en esas reflexiones que el tribunal oral se hizo debido cargo de las probanzas rendidas, efectuando una reproducción de los mecanismos de valoración, así como la ponderación que se hizo de cada uno de los medios de prueba y que lo llevaron a adquirir dicha convicción de condena, parecer que no fue compartido por el respectivo tribunal de alzada conforme ya se refrendó en motivos anteriores, constatación que permite rechazar cualquier atisbo de ser la primera una resolución judicial injustificadamente errónea o arbitraria, pues en ningún caso carecía de una explicación lógica, de motivación y racionalidad, ni fue dictada de manera irregular o caprichosa, de modo que no se satisface ninguna de las condiciones que de acuerdo la Carta Fundamental hacen procedente la declaración que corresponde a esta Corte Suprema, lo que conlleva a que la interpuesta a fojas 50 no puede prosperar". ${ }^{109}$
\end{abstract}

Por otro lado, la Corte estima que no es injustificadamente erróneo o arbitrario el auto de procesamiento se basa en antecedentes que permiten presumir la existencia del delito y la participación del imputado, es decir, cuando cumple los requisitos que impone el artículo

\footnotetext{
${ }^{108}$ SCS rol n³815-2006.

${ }^{109}$ SCS rol n5269-2011 considerando $21^{\circ}$.
} 


\section{Polít. Crim. Vol. 14, No 28 (Diciembre 2019), Art. 6, pp. 216-268. [http://politcrim.com/wp-content/uploads/2019/12/Vol14N28A6.pdf]}

274 del Código de Procedimiento Penal. ${ }^{110}$ En este mismo sentido, la Corte señala que no es injustificadamente errónea o arbitraria la resolución que decreta y mantiene la prisión preventiva que "se adoptó en base a elementos objetivos, principalmente fundándose en la declaración de una víctima que mantuvo invariablemente su versión hasta el juicio oral, por lo que incluso de estimarse equivocada tal decisión, no se trata de un error manifiesto o inaceptable, menos de una decisión antojadiza y carente de razón". ${ }^{111}$ En definitiva, existiendo antecedentes (o al menos un antecedente) que respalde la decisión adoptada por el tribunal, la resolución no será injustificadamente errónea o arbitraria.

Incluso la Corte aplica este razonamiento en un caso de error en la identidad del imputado en que se detuvo, formalizó y sujetó a la medida cautelar de firma mensual a un sujeto que había usurpado la identidad del solicitante, quien posteriormente fue detenido por incumplir la cautelar impuesta. En este contexto, la Corte explica que el Ministerio Público

"es el encargado de dirigir en forma exclusiva la investigación de los hechos constitutivos de delito, los que determinan la participación punible y los que acreditan la inocencia del imputado en la forma prevista por la Constitución y la ley", ${ }^{112}$ mientras que "al Juez de Garantía corresponde, por su parte, hacer una valoración de aquellos antecedentes que han sido aportados por ambas partes y que le permiten adoptar una decisión sobre la pertinencia de decretar, mantener o revocar tal o cual medida cautelar" (las cursivas son nuestras). ${ }^{113}$

De esta manera, no es injustificadamente errónea o arbitraria la resolución que decreta medidas cautelares que se dicta basándose en los antecedentes aportados por el Ministerio Público, aunque éstos hayan estado equivocados en cuanto a la identidad del autor del delito.

Por otro lado, existe un grupo de 10 de resoluciones ${ }^{114}(15,2 \%$ del universo total de casos y $21,7 \%$ del total de rechazos) en que la Corte no ofrece definición alguna de los conceptos estudiados, ni siquiera conjuntamente, sino que simplemente se limita a descartar su existencia porque la resolución tiene suficiente sustento en los antecedentes del proceso, es decir, explicitando el antónimo de lo que hemos venido diciendo hasta ahora. En este orden de ideas, la Corte utiliza diversas frases para señalar que existirían "antecedentes", "elementos de convicción" o "elementos objetivos" que "otorgan razonabilidad a la resolución", de manera que habría "mérito suficiente" para dictarla.

También, existen otras sentencias en que la Corte Suprema no analiza los hechos a la luz del concepto en estudio, o al menos no explícitamente, sino que primero examina los antecedentes que existían al momento de dictar la resolución impugnada, la actitud de la defensa y otros elementos del caso para luego afirmar que, en virtud de aquellos, la resolución no es injustificadamente errónea o arbitraria, sin ofrecer un concepto o explicitar

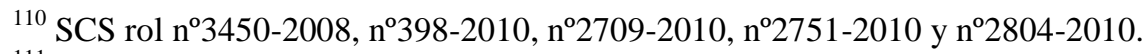

${ }^{111}$ SCS rol n $33813-2017$ considerando $7^{\circ}$.

${ }^{112}$ SCS rol n ${ }^{\circ} 5572-2007$ considerando $13^{\circ}$.

${ }^{113}$ SCS rol n $5572-2007$ considerando $13^{\circ}$.

${ }^{114}$ SCS rol nº190-2007, $\mathrm{n}^{\mathrm{o}} 498-2008, \mathrm{n}^{\circ} 7837-2010, \mathrm{n}^{\circ} 7279-2012,7937-2012,7939-2012, \mathrm{n}^{\circ} 7945-2012$, 8050-2012, 587-2013 y 70829-2016.
} 
por qué no atribuye esta calificación. ${ }^{115}$ Sin embargo, al darse la molestia de nombrar los antecedentes que fundaron la sentencia, la Corte parece indicarnos que su existencia es la causa de rechazo de la solicitud.

A continuación, en la tabla ${ }^{\circ} 10$ incluimos un cuadro resumen de lo que ha sido expuesto en esta sección, señalando las diversas definiciones que ha dado la Corte y la forma en que se han aplicado a los casos en concreto.

${ }^{115}$ SCS rol no22356-2014 y 22498-2014. 


\section{Polít. Crim. Vol. 14, Nº 28 (Diciembre 2019), Art. 6, pp. 216-268. [http://politcrim.com/wp-content/uploads/2019/12/Vol14N28A6.pdf]}

Tabla $\mathrm{n}^{\mathrm{o}} 10$ :

Resumen definiciones y aplicaciones realizadas por la Corte para rechazar, años 2006-2017

Fuente: Elaboración propia

\begin{tabular}{|c|c|c|}
\hline $\begin{array}{c}\text { Resolución injustificadamente } \\
\text { errónea }\end{array}$ & Resolución arbitraria & $\begin{array}{c}\text { Resolución injustificadamente } \\
\text { errónea o arbitraria }\end{array}$ \\
\hline \multicolumn{3}{|c|}{ DEFINICIONES } \\
\hline $\begin{array}{l}\text { 1) Una resolución es } \\
\text { injustificadamente errónea cuando } \\
\text { los razonamientos que la conducen } \\
\text { al resultado inexacto no } \\
\text { convencen (no son convincentes), } \\
\text { cuando no son susceptibles de una } \\
\text { explicación razonable (racional) } \\
\text { cuando, en fin, son contrarios a la } \\
\text { lógica, a los dictados de la } \\
\text { experiencia y a los conocimientos } \\
\text { más difundidos sobre la materia } \\
\text { respecto a la cual versa. } \\
\text { 2) El error judicial debe ser } \\
\text { manifiesto, craso, que es el que no } \\
\text { admite excusa ni razón para } \\
\text { explicarlo }\end{array}$ & $\begin{array}{l}\text { 1) Arbitrario es aquello contrario } \\
\text { a la justicia, la razón o las leyes, } \\
\text { vale decir, cuando se lo ha } \\
\text { dictado obedeciendo sólo a la } \\
\text { voluntad o al capricho. } \\
\text { 1.1) ...o que carezca de } \\
\text { motivación o racionalidad. }\end{array}$ & $\begin{array}{l}\text { 1) Es aquella que se dictó sin existir } \\
\text { elementos de convicción que } \\
\text { permitieran fundarla racionalmente, } \\
\text { o se expidió por voluntad } \\
\text { meramente potestativa, caprichosa o } \\
\text { insensata. } \\
\text { 2) Resolución judicial carente de } \\
\text { toda justificación, sin motivo o } \\
\text { causa plausible, sin fundamento } \\
\text { racional, cometiéndose un error } \\
\text { craso. } \\
\text { 3) Resolución judicial que } \\
\text { contradice a la razón, que es } \\
\text { inexcusable, que ha sido decretada } \\
\text { de manera irregular o caprichosa, } \\
\text { que carece de una explicación } \\
\text { lógica, de motivación y } \\
\text { racionalidad. }\end{array}$ \\
\hline \multicolumn{3}{|c|}{ APLICACIÓN } \\
\hline $\begin{array}{l}\text { Un auto de procesamiento no es } \\
\text { injustificadamente erróneo cuando } \\
\text { existen múltiples antecedentes que } \\
\text { (1) justifican la existencia del } \\
\text { delito y (2) permiten presumir } \\
\text { fundadamente que el inculpado ha } \\
\text { tenido participación en el delito } \\
\text { como autor, cómplice o } \\
\text { encubridor (requisitos que impone } \\
\text { el artículo } 274 \text { del Código de } \\
\text { Procedimiento Penal). }\end{array}$ & $\begin{array}{l}\text { Argumenta que la resolución no } \\
\text { es injustificadamente errónea por } \\
\text { estar fundada en múltiples } \\
\text { antecedentes y luego señala: } \\
\text { Que, por lo mismo, tampoco } \\
\text { puede apreciarse que haya sido } \\
\text { arbitraria. }\end{array}$ & $\begin{array}{l}\text { No es injustificadamente erróneo o } \\
\text { arbitrario el auto de procesamiento } \\
\text { se basa en antecedentes que } \\
\text { permiten presumir la existencia del } \\
\text { delito y la participación del } \\
\text { imputado, es decir, cuando cumple } \\
\text { los requisitos que impone el artículo } \\
274 \text { del Código de Procedimiento } \\
\text { Penal. }\end{array}$ \\
\hline \multirow[t]{2}{*}{$\begin{array}{l}\text { Una sentencia condenatoria no es } \\
\text { injustificadamente errónea si la } \\
\text { decisión de los jueces se ajusta al } \\
\text { mérito del proceso, es decir, se ha } \\
\text { fundado sobre la base de las } \\
\text { pruebas suministradas, la que debe } \\
\text { haber sido ponderada libremente, } \\
\text { como lo señala el Código Procesal } \\
\text { Penal. }\end{array}$} & $\begin{array}{l}\text { Argumenta conjuntamente que la } \\
\text { resolución no es } \\
\text { injustificadamente errónea o } \\
\text { arbitraria a pesar de haber } \\
\text { definido los conceptos } \\
\text { separadamente. }\end{array}$ & $\begin{array}{l}\text { La sentencia condenatoria no es } \\
\text { injustificadamente errónea o } \\
\text { arbitraria porque contiene una } \\
\text { exposición de las probanzas y un } \\
\text { desarrollo claro y lógico que } \\
\text { permite comprender cómo se llega a } \\
\text { las conclusiones que se indican y a } \\
\text { los hechos que se dan por } \\
\text { establecidos }\end{array}$ \\
\hline & $\begin{array}{l}\text { La sentencia condenatoria no es } \\
\text { arbitraria, por contener } \\
\text { explícitamente los argumentos } \\
\text { que la llevaron a condenar. }\end{array}$ & $\begin{array}{l}\text { La resolución que decreta prisión } \\
\text { preventiva no es injustificadamente } \\
\text { errónea o arbitraria puesto que el } \\
\text { Ministerio tenía varios antecedentes } \\
\text { que la defensa no logró desvirtuar. }\end{array}$ \\
\hline
\end{tabular}




\begin{tabular}{|l|l|l|}
\hline & $\begin{array}{l}\text { La resolución que decreta prisión } \\
\text { preventiva no es injustificadamente } \\
\text { errónea o arbitraria puesto que se } \\
\text { adoptó en base a elementos } \\
\text { objetivos, principalmente } \\
\text { fundándose en la declaración de una } \\
\text { víctima. }\end{array}$ \\
\hline & $\begin{array}{l}\text { La resolución que condena a un } \\
\text { imputado erróneamente identificado } \\
\text { no es injustificadamente errónea o } \\
\text { arbitraria puesto que el juez se basó } \\
\text { en los antecedentes aportados por el } \\
\text { Ministerio Público. }\end{array}$ \\
\hline
\end{tabular}

Siendo el argumento de no estar en presencia de una resolución injustificadamente errónea o arbitraria la principal barrera identificada para obtener la indemnización por error judicial, resulta trascendental comprender qué entiende la Corte cuando interpreta esta frase en la norma constitucional. En este contexto, hemos podido determinar que muchas veces separa estos conceptos entendiendo que se trata de hipótesis diversas, otras los define conjuntamente y otras no ofrece definición alguna. Con todo, una constante común que aparece en la investigación es que en todos los casos lo decisivo sería la existencia de antecedentes en el caso que respalden la decisión del juez o tribunal, de manera que, si existe al menos uno, se rechaza la idea de que se trate de una resolución injustificadamente errónea o arbitraria. La Corte, sin embargo, no evalúa el fondo de la prueba, de manera que la calidad de dichos antecedentes no parece ser determinante a la hora de decidir. Es probable que en muchos casos no sea posible exigir que la Corte haga un análisis de este tipo, puesto que, por las características del tipo proceso, no está en condiciones de hacerlo. Piénsese en los casos del sistema acusatorio en que sólo se puede acceder a la prueba a través de la descripción que hace de ella la sentencia definitiva escrita o en la gran cantidad de resoluciones orales que se pronuncian en este sistema, dictadas en virtud de antecedentes y discusiones que se presentan en audiencias que sólo pueden conocerse a través de transcripciones o sus respectivos audios. Existe, por lo tanto, una barrera estructural que impide a la Corte realizar un análisis más profundo de la calidad de los antecedentes para determinar si la resolución es injustificadamente errónea o arbitraria.

\section{Resoluciones que acogen la solicitud}

En esta sección explicaremos las cuatro resoluciones de la Corte Suprema que acogen la solicitud previa a la indemnización por error judicial en el período 2006-2017 organizadas en forma cronológica.

\subsection{Caso María Yáñez (rol $n^{\circ}$ 5411-2010)}

El primer caso en que la Corte Suprema estimó que la resolución dictada fue injustificadamente errónea concierne a María Yáñez, abogada, cuya identidad fue suplantada. Según los hechos relatados en la sentencia, el año 2002 fue sustraída la cartera y cédula de identidad de la solicitante, mientras que, en octubre del mismo año, una mujer es detenida al interior de un supermercado después de cometer un ilícito, sin portar su 


\section{Polít. Crim. Vol. 14, No 28 (Diciembre 2019), Art. 6, pp. 216-268. [http://politcrim.com/wp-content/uploads/2019/12/Vol14N28A6.pdf]}

cédula de identidad, por lo que al pedirle identificación afirma ser María Yáñez e indica el Rut que correspondía a ese nombre. La mujer detenida confesó haber cometido el hurto imputado, por lo que fue sometida a proceso y posteriormente se le otorgó libertad provisional, sin que nadie exigiera la exhibición de su cédula de identidad u otro documento idóneo, registrara sus huellas dactilares o enviado a prontuariar, antes de ordenar su libertad. Finalmente, fue condenada por el Vigésimo Juzgado del Crimen de Santiago como autora del delito de hurto frustrado a cumplir cuarenta y un días de prisión en su grado máximo, condena que jamás pudo ser notificada personalmente. En septiembre del 2008, "la verdadera" María Yáñez es detenida en el aeropuerto y mantenida privada de libertad por tres días hasta que es puesta a disposición del Juez competente. Ante esta situación se deduce recurso de revisión, el que es acogido por la Corte Suprema, invalidando el fallo condenatorio y absolviéndola del cargo formulado. ${ }^{116}$

Para afirmar el carácter "injustificadamente erróneo o arbitrario" la solicitante sostiene que implícitamente ello habría sido reconocido por la Corte Suprema en el fallo de revisión. Afirma que el juez de primera instancia cometió un "grave error judicial" al condenarla y que "no condujo adecuadamente la causa". La solicitante no ofrece un concepto de "error injustificado" o "arbitrariedad" ni especifica cómo los hechos relatados concuerdan con esta calificación.

Tanto el Consejo de Defensa del Estado como la Fiscal suplente de la Corte Suprema solicitan la inadmisibilidad del recurso por no haberse adjuntado los documentos exigidos por el Auto Acordado que regula esta solicitud y, respecto al fondo, piden su rechazo puesto que no se trataría de una resolución injustificadamente errónea o arbitraria. El Consejo de Defensa estima que para calificar de tal modo la resolución, debe advertirse "capricho o irracionalidad" en el actuar del juez, lo que no concurre en este caso, ya que la única persona responsable sería la suplantadora, que al no concurrir a prontuariarse, no sólo engañó a la recurrente sino también a la policía y al tribunal. Por otro lado, la Fiscal de la Corte señala que no se trata de una resolución injustificadamente errónea o arbitraria, puesto que existían antecedentes suficientes para dictar el auto de procesamiento y la condena (entre ellas, la confesión de la imputada y la incriminación en su contra por las otras dos mujeres que fueron detenidas con ella), por otro lado, según la historia fidedigna del establecimiento de la ley, una resolución tiene estas características cuando "es carente de motivación alguna, sin fundamento o causa plausible o pronunciada con error grave, sin justificación racional o inexplicable", lo que no es posible afirmar respecto del auto de procesamiento impugnado. ${ }^{117}$

En el considerando tercero, la Corte concuerda con el Consejo de Defensa Estado y la Fiscal en el sentido de que existía merito suficiente para dictar el auto de procesamiento y sentencia condenatoria. Sin embargo, el juez incurrió en una omisión al no verificar la

\footnotetext{
${ }^{116}$ Recurso de revisión tramitado por la Corte Suprema bajo el rol n³99-2009. Cabe señalar que en un estudio sobre los recursos de revisión en casos del sistema acusatorio resueltos en el período 2007-2016 por la Corte Suprema se pudo establecer que los casos de suplantación de identidad constituyeron 40 de los 48 recursos acogidos. DUCE, "Los recursos de revisión", cit. nota nº 7, pp. 24-26.

${ }^{117}$ Los argumentos de ambas partes son descritos por la Corte Suprema en la sección "vistos" de la Sentencia Rol n5411-2010.
} 
identidad de la delincuente, lo que produjo en error en la tramitación del proceso que afectó cada una de las etapas siguientes (considerando cuarto) y, si bien fueron jueces diferentes los que intervinieron en las distintas etapas "todos ellos debieron advertir el error subyacente, lo que no hicieron, actuando cual más cual menos con mayor descuido al dictar resoluciones cada vez más trascendentes" (considerando décimo). La Corte estimó que, en virtud de diversas normas del Código de Procedimiento Penal, existía la obligación de verificar la identidad de la imputada y, en cambio

“el juez no sólo se quedó con la sola declaración de la delincuente acerca de su identificación, sino que además, junto con someterla a proceso, la liberó, sin que conste en el proceso que la haya apercibido de concurrir a firmar el libro de excarcelados con la periodicidad dispuesta por él y sin que tampoco se le haya dado la orden de concurrir a prontuariarse. Por cierto, además, no se tomó siquiera la precaución de registrar sus huellas dactilares antes de liberarla" (considerando séptimo).

Este error en la tramitación del proceso sería "injustificadamente erróneo" a pesar de que las resoluciones tenían mérito suficiente en virtud de los antecedentes reunidos, puesto que "no lo tenían (mérito) en el aspecto subjetivo, esto es, en relación al sujeto de la imputación, por la falta de documentos o elementos idóneos para cotejar su identificación, circunstancia claramente atribuible a una negligente actuación de la autoridad jurisdiccional" (considerando undécimo).

Por estas consideraciones, la Corte acoge la solicitud presentada por doña María Yáñez y declara que tanto el auto de procesamiento como la sentencia definitiva dictados por el Vigésimo Juzgado del Crimen de Santiago, fueron injustificadamente erróneos. La sentencia en estudio fue acordada con el voto en contra del ministro señor Rodríguez, quien estuvo por rechazar la solicitud, puesto que "tanto para pronunciar el auto de procesamiento, como para dictar sentencia condenatoria, vistas objetivamente, ellas tenían el mérito suficiente para ese efecto, de modo que no ha existido error en el fondo, en la valoración de los cargos" (considerando primero). Por otro lado, el Ministro afirma que los errores en la tramitación del proceso (superar una etapa y pasar a la siguiente sin verificar la identidad del delincuente) no pueden calificarse como injustificadamente erróneos o arbitrarios, puesto que, como indica el artículo 260 del Código de Procedimiento Penal, la tarea de identificación de cualquier persona "se encomienda expresamente a la policía y no al tribunal, que ni siquiera tiene intervención en la diligencia", por tanto, se trata de un caso de responsabilidad administrativa que debe ejercerse del mismo modo que todas aquellas que son contenciosas administrativas y que no tienen señalado un procedimiento especial (considerando segundo). Como tercer argumento, el ministro señala que el artículo $274 \mathrm{n}^{\circ} 2$ del mismo cuerpo legal "se refiere expresamente a la participación del encausado en el delito y no a su identificación, amén de su naturaleza eminentemente provisional". Finalmente, señala que la responsable de los perjuicios que sufrió la solicitante

"fue la persona que la suplantó, unido a la pérdida de la cédula de identidad de la suplantada, la cual indujo a la policía a suministrar información equivocada al tribunal" y "en el evento que alguien supuestamente pudiere incurrir en error injustificado y arbitrariedad, sería la policía que habría omitido identificar en debida 


\section{Polít. Crim. Vol. 14, No 28 (Diciembre 2019), Art. 6, pp. 216-268. [http://politcrim.com/wp-content/uploads/2019/12/Vol14N28A6.pdf]}

forma a una mujer detenida cuando acababa de cometer un hurto" (considerado sexto).

Una vez obtenida la declaración previa que exige el artículo 19 n ${ }^{\circ} 7$ letra i), se demandó al Estado por la suma de \$103.777.445 ante el $14^{\circ}$ Juzgado Civil de Santiago, el que condenó al Fisco de Chile a pagar a la demandante la suma de $\$ 30.000 .000$ por concepto de daño moral, más reajustes e intereses. ${ }^{118}$ En cumplimiento de dicha condena, el Ministerio de Justicia resolvió el 14 de julio de 2015, por orden del Presidente de la República, que la Tesorería Regional Metropolitana debía pagar un total de $\$ 30.218 .311$. ${ }^{119}$

\subsection{Caso Mauricio Hernández (rol no 25658-2014)}

En la segunda solicitud acogida por la Corte Suprema, Mauricio Hernández, también abogado, solicita que se declare injustificadamente erróneo el auto de procesamiento y posterior sentencia condenatoria dictados por el $3^{\circ}$ Juzgado del Crimen de Santiago, en que se le condenó como autor del delito de estafa del artículo $470 n^{\circ} 8$ del Código Penal, por haber engañado al Tribunal al interponer una demanda de indemnización de perjuicios en contra del Servicio de Impuestos Internos por el retardo de una devolución de impuestos, usando una ley vigente al momento de formular la solicitud y no aquella que era aplicable en la fecha en que ocurrieron los hechos y que prohibía dicha devolución. Sin embargo, el solicitante señala que en realidad no impetró la devolución del impuesto, sino una solicitud que se oficiara a Tesorería para continuar con el trámite, entidad que bien pudo negarse, no obstante, cursó el reintegro, proceder avalado por la Contraloría General de la República.

El solicitante señala que el auto de procesamiento y subsecuente sentencia condenatoria de primera instancia eran injustificadamente erróneas puesto que él actuó en ejercicio legítimo de su profesión y del derecho de petición, sin efectuar ninguna puesta en escena, ni adjuntar documentación falsa o incompleta. Señala que incluso de estimarse engañoso su requerimiento, se trataría de un embuste inidóneo puesto que el tribunal tuvo a la vista todos los antecedentes para resolver con arreglo a derecho y, sin embargo, los ponderó irracionalmente, lo que condujo a que fuera procesado, privado de libertad por tres días y condenado.

El Consejo de Defensa del Estado y la Fiscal Judicial recurren a las definiciones utilizadas anteriormente por la Corte Suprema respecto al concepto de "error injustificado". En efecto, el Consejo de Defensa lo define como una resolución "asociada a la irracionalidad o un capricho" (considerando tercero) y la Fiscal Judicial, utiliza exactamente la misma definición -y que se transcribe más adelante-, pero añade elementos que aumentan significativamente el estándar, tales como:

"contrario a la justicia o las leyes", "cuando no hay elementos que intelectualmente a una mente normal puedan haberla llevado a una misma conclusión", "decisión

\footnotetext{
118 Sentencia definitiva dictada el 8 de septiembre del 2014 por el $14^{\circ}$ Juzgado Civil de Santiago en la causa Rol C-20189-2012.

${ }^{119}$ Resolución exenta número ilegible de 14 de julio de 2015 del Ministerio de Justicia (se encuentra la copia de dicha resolución en el expediente del 14 Juzgado Civil de Santiago, causa Rol C-20189-2012 en foja 399).
} 
carente de motivación alguna, sin motivo o causa plausible, por un error grave sin fundamento racional, inexplicable, cometiendo un craso error", "si media infracción a los deberes esenciales del juez, una ausencia absoluta de análisis, un actuar de mala fe, sin elementos que autoricen proceder como se hizo" (considerando cuarto).

Como puede apreciarse, las frases que agrega el Consejo de Defensa del Estado pasan a exigir contravención de normas legales o deberes del juez, ausencia absoluta de fundamentos y un actuar doloso del juez en este sentido, lo que va más allá de exigir "actuaciones de la judicatura desprovistas de elementos de convicción" o "expedidas por voluntad meramente potestativa, caprichosa o insensata" como lo hace la Corte. En este contexto, ambos intervinientes afirman que las dos resoluciones impugnadas se basaron en los antecedentes del caso y, en este sentido, cumplieron con los estándares normativos exigidos por los artículos 274 y 456 bis del Código de Procedimiento Penal. Sobre la base de estos argumentos, ambos actores entienden que en el caso concreto no hay un error injustificado y por tanto debe desestimarse la solicitud.

La Corte estimó que la resolución impugnada había sido injustificadamente errónea por arribar a una conclusión que no podía sustentarse en los antecedentes del caso. En efecto, la Corte señala:

\begin{abstract}
"estaba claro, ya en la etapa sumarial, que la conducta del querellado, en que se hizo consistir la acción reprimida en el artículo 470, $\mathrm{N}^{\circ} 8$, del Código Penal no era constitutiva de un engaño..." (considerando séptimo) “...que tanto el auto de procesamiento como la sentencia condenatoria de primera instancia que declararon equivocadamente que la solicitud formulada, propia del ejercicio profesional del abogado, configura un engaño ínsito en el tipo penal del artículo 470, $\mathrm{N}^{\circ} 8$, del Código sancionatorio, sin otros elementos de convicción que acrediten racionalmente las maniobras mentirosas, dado que el contexto fáctico latamente descrito impedía, desde los inicios del procedimiento penal, tener por justificada la existencia del delito" (considerando octavo).
\end{abstract}

En este sentido, la Corte no concuerda con los dichos de los demás intervinientes en orden a estimar que las resoluciones se basaron en los antecedentes del caso, puesto que los existentes demostraban la existencia de una conducta atípica. En este sentido, el Juez del Crimen incumplió uno de sus deberes básicos: valorar correctamente la prueba.

En definitiva, la Corte acoge la solicitud de declaración previa de error judicial y, por consiguiente, declara que la resolución que sometió a proceso a Mauricio Hernández y la sentencia definitiva que lo condenó dictadas por el $3^{\circ}$ Juzgado del Crimen de Santiago, son resoluciones injustificadamente erróneas. La sentencia es unánime.

Obtenida la declaración previa que exige nuestra norma constitucional, Mauricio Hernández demandó al Fisco ante el $9^{\circ}$ Juzgado Civil de Santiago por la suma de $\$ 381.455 .200$. En dicho proceso se condena al Fisco a pagar la suma de \$118.505.200 más reajustes e intereses. ${ }^{120}$ Dicha resolución fue confirmada por la Corte de Apelaciones de Santiago, salvo en aquella parte que libera a la demandada del pago de las costas de la

${ }^{120}$ Sentencia dictada por el $9^{\circ}$ Juzgado Civil de Santiago de 22 de junio de 2016 en causa rol C-14666-2015. 


\section{Polít. Crim. Vol. 14, No 28 (Diciembre 2019), Art. 6, pp. 216-268. [http://politcrim.com/wp-content/uploads/2019/12/Vol14N28A6.pdf]}

causa, decidiendo en su lugar, que deberá hacer frente a su importe. ${ }^{121}$ En cumplimiento de dicha sentencia, el 7 de agosto de 2017 el Ministerio de Justicia, por orden del Presidente de la República, resuelve que la Tesorería Regional Metropolitana deberá pagar la suma de $\$ 136.126 .945 .{ }^{122}$

\subsection{Caso Leonardo General Chavarría (rol n⿳1579-2015)}

En la tercera solicitud acogida por la Corte, se reclama de las resoluciones sobre medidas cautelares dictadas por un Juzgado de Garantías que mantienen a Leonardo General Chavarría en prisión preventiva por más de tres meses y sujeto a arresto domiciliario nocturno por nueve meses frente a una imputación de ser autor del delito de violación, por ser injustificadamente erróneas. Estas resoluciones se basaron, entre otros antecedentes, en un video grabado por la víctima en que supuestamente se mostraba que el imputado la habría accedido vaginalmente bajo intimidación. Sin embargo, la defensa del imputado indicó que las conductas denunciadas habrían sido consentidas por la supuesta víctima y cuándo solicitaron la obtención del video para probar que se trataría de un montaje, primero al Ministerio Público y luego al tribunal mediante cautela de garantías, éste le fue denegado. El montaje fue acreditado posteriormente por el Tribunal de Juicio Oral, quien lo absolvió de los cargos declarando que no había antecedentes que acrediten un actuar coactivo de su parte.

Según el solicitante, el error reside en decretar la prisión preventiva y mantener esa medida, así como rechazar la cautela de garantías con la que se buscaba oír el audio, diligencia que habría permitido descubrir el montaje de la supuesta víctima.

Tanto el Consejo de Defensa del Estado como la Fiscal Judicial piden que se rechace la solicitud, porque las resoluciones impugnadas no resultaban carentes de todo fundamento o justificación, puesto que existían una serie de antecedentes o indicios respecto de la comisión del delito investigado además del video (considerandos segundo y tercero). El Consejo agrega, adicionalmente, que debe rechazarse la solicitud puesto que la prisión preventiva es una medida cautelar que no equivale al antiguo auto de procesamiento al que alude el artículo $19 \mathrm{n}^{\circ} 7$ letra i), invocando así lo que había sido la doctrina prevalente de la Corte hasta el año 2014 como hemos mencionado.

La Corte Suprema descarta que la resolución que decreta la prisión preventiva no pueda puedan ser objeto de la declaración que pretende la solicitud y, además, excluye del análisis el actuar del Ministerio Público, por existir otro procedimiento adecuado para reclamar de él.

Al decidir el caso, la Corte señala que, al momento de decretar la prisión preventiva, no se presentaron los demás antecedentes distintos al video aludidos por la Fiscal y Consejo de Defensa, sino que sólo son incorporados en el juicio oral. Por otro lado, la defensa no cuestiona la ocurrencia de los hechos, sino sólo la existencia de fuerza o intimidación, de

\footnotetext{
${ }^{121}$ Sentencia dictada por la Corte de Apelaciones de Santiago el 6 de enero de dos mil diecisiete, en causa rol $\mathrm{n}^{\circ}$ 9250-2016.

${ }^{122}$ Resolución exenta nº 2556 del Ministerio de Justicia del 7 de agosto del 2017.
} 
DUCE, Mauricio; VILLARROEL, Romina, “Indemnización por error judicial: una aproximación empírica a la jurisprudencia de la Corte Suprema de los años 2006-2017”

modo que resulta patente la escasez e insuficiencia de los antecedentes proporcionados por el Ministerio Público para justificar la existencia de dichos elementos (considerandos séptimo y octavo). Por lo demás, los antecedentes existentes sólo consistían en la declaración de la víctima y de su conviviente, que es sólo testigo de oídas, siendo el relato de aquélla carente de racionalidad y mínima sensatez, mientras que el video no aportaba indicio alguno que permitiera descartar una relación sexual consentida. Al contrario, el video mostraba cómo la mujer quitaba el pestillo a la puerta para dejar entrar al acusado y realizar conductas propias o comunes de un acto sexual consentido entre adultos. De esta forma, ninguno de los antecedentes daba cuenta de elementos serios que avalaran la conclusión del tribunal de tener por "acreditado" el delito materia de la formalización. Ello también se veía ratificado por el propio tenor de la resolución que nada decía o precisaba para justificar la concurrencia del elemento "fuerza o intimidación", ni siquiera anunciaba qué antecedente de los expuestos por el fiscal sustentaba su convicción en este punto, silencio que se explicaba por la imposibilidad de construir tal determinación "y de ahí que esa decisión resulta desprovista de elementos de convicción que habiliten su sustento racional, en definitiva, injustificadamente erróneo" (considerando noveno).

Por estas consideraciones, la Corte acoge unánimemente la solicitud de declaración previa de error judicial y, por consiguiente, declara que la resolución que sometió al solicitante a prisión preventiva y la que le impuso la medida cautelar de arresto domiciliario nocturno dictadas por el Juzgado de Garantías de Los Andes fueron injustificadamente erróneas.

Leonardo General Chavarría demandó al Fisco por la suma de $\$ 211.000 .000$ ante el $12^{\circ}$ Juzgado Civil de Santiago, tribunal que acoge parcialmente la demanda y condena al Fisco a pagar a título de indemnización de perjuicios la suma de $\$ 45.000 .000$, más reajustes e intereses. ${ }^{123}$ Dicha resolución fue apelada ante la Ilustrísima Corte de Apelaciones de Santiago y ésta la confirmó el día 8 de noviembre de $2018 .^{124}$

\subsection{Caso Ernesto Galaz (SCS n⿳11486-2017)}

En este caso la Corte declara injustificadamente errónea la sentencia del Tribunal de Justicia Militar en Tiempos de Guerra que condena a muerte a Ernesto Galaz Guzmán, pena que posteriormente fue modificada por presidio y, ésta, a su vez, sustituida por extrañamiento. La solicitud señala que luego del golpe de Estado de septiembre de 1973, fue detenido ilegalmente, torturado, sometido a Consejo Guerra y condenado a muerte como autor de delitos de incumplimiento de deberes militares, traición, promoción a la sedición, y otros delitos. Una vez recuperada la democracia, abre un proceso ante la Corte Interamericana de Derechos Humanos la que, por sentencia de 2 de septiembre de $2015,{ }^{125}$ ordenó al Estado de Chile adoptar las medidas legislativas, administrativas o de cualquier índole, adecuadas para que personas condenadas por Consejos de Guerra durante la dictadura, vieran revisadas y anuladas las sentencias condenatorias dictadas en procesos

\footnotetext{
${ }^{123}$ Sentencia del $12^{\circ}$ Juzgado Civil de Santiago del 28 de noviembre del 2017 dicta causa rol C-16379-2016.

${ }^{124}$ Causa rol n ${ }^{\circ} 1772-2018$ de la Corte de Apelaciones de Santiago. Esta decisión se encuentra ejecutoriada según se certificó en la causa el 10 de diciembre de 2018.

${ }_{125}$ Sentencia Corte Interamericana de Derechos Humados de 2 de septiembre de 2015 "Omar Humberto Maldonado Vargas Y Otros Vs. Chile".
} 


\section{Polít. Crim. Vol. 14, No 28 (Diciembre 2019), Art. 6, pp. 216-268. [http://politcrim.com/wp-content/uploads/2019/12/Vol14N28A6.pdf]}

que pudieron haber tomado en cuenta pruebas o confesiones obtenidas bajo tortura, como fue su caso. En cumplimiento de esta disposición el Consejo de Defensa se dirigió al Fiscal Judicial de la Corte Suprema para interponer un recurso de revisión en contra de la sentencia condenatoria, el que fue acogido por sentencia de 3 de octubre de 2016, invalidando el fallo en cuestión y declarando la absolución del solicitante por haber sido probada satisfactoriamente su completa inocencia. ${ }^{126}$

El Consejo de Defensa del Estado, por su parte, solicita la declaración de inadmisibilidad de la solicitud y, subsidiariamente, su rechazo, puesto que ya había sido reparado por el Estado con el pago de la suma de US\$25.000, como lo ordenó la Corte Interamericana. En segundo lugar, señala que el Consejo de Guerra constituye una comisión especial, de modo que no sería un órgano encargado de la administración de justicia, mientras que las normas invocadas establecen un régimen de responsabilidad del Estado por actos del Poder Judicial. La Fiscal Judicial, en cambio, concuerda con la solicitud, siendo una de las cuatro veces en el período en estudio en que adopta esta postura y la primera en que la Corte acoge sus argumentos en este sentido.

La Corte Suprema desestima los argumentos del Consejo de Defensa del Estado en cuanto que los perjuicios padecidos por el solicitante ya habrían sido indemnizados, puesto que se trataría de una excepción de fondo que debía ser ventilada en el procedimiento civil de indemnización. La Corte también estima que las sentencias impugnadas en esta causa tenían el carácter de decisión emanada de un órgano jurisdiccional, al punto de estimarlas susceptibles de ser invalidadas por la vía del recurso de revisión, por lo que no es posible admitir las alegaciones que les niegan el referido carácter. Para hacer tal afirmación se basa en dos argumentos. En primer lugar, porque los argumentos del Consejo de Defensa contravienen la doctrina los actos propios, puesto que este mismo interviniente había argumentado a favor de la solicitud de revisión reconociendo lo que ahora niega: el carácter de resolución emanada de un órgano jurisdiccional (considerando noveno). En segundo lugar, que los Tribunales Militares en Tiempo de Guerra hayan actuado en contra de las disposiciones del Código de Justicia Militar, que los regla, y hayan actuado "excediendo sus atribuciones y en abierta vulneración del estatuto que justificaba su constitución, competencia y procedimiento, no quita el carácter de acto amparado por la presunción de juricidad que tuvieron tales dictámenes, los que surtieron todos sus efectos al haberse impuesto coercitivamente a los condenados el cumplimiento de las penas que se determinaron, entre ellos el requirente de autos" (considerando décimo).

En cuanto al fondo, la Corte estima que se está en presencia de una decisión injustificadamente errónea en el caso, puesto que, tal como se indicó en el fallo de revisión, una vez demostrado el método de tortura utilizado para obtener las confesiones del solicitante, éstas no podían sustentar las condenas impuestas, de forma que prescindiendo de esas confesiones y declaraciones no quedan elementos probatorios que permitieran a los Consejos de Guerra alcanzar la convicción condenatoria en las sentencias objeto de

\footnotetext{
${ }^{126}$ Sentencia Corte Suprema de 3 de octubre de 2016 causa Rol n²7543-2016 Caratulado "Juan Escobar Zepeda (Fuerza Aérea De Chile Contra Bachelet Y Otros)".
} 
revisión. La Corte señaló que "la condena del actor fue consecuencia de una actuación de la judicatura militar carente de elementos de convicción que la fundamentaran racionalmente, por lo que no cabe si no concluir que tal decisión fue injustificadamente errónea, al ser consecuencia de una voluntad meramente potestativa".

Finalmente, la Corte acoge la solicitud de declaración previa de error judicial y, por consiguiente, declara que las sentencias condenatorias dictadas por el Tribunal Militar en Tiempos de Guerra respecto a don Ernesto Galaz Guzmán, son injustificadamente erróneas. La sentencia fue dictada por unanimidad, con la prevención del ministro señor Künsemüller que tiene en cuenta, además, que de acuerdo al Código de Justicia Militar no es factible sostener que los Consejos de Guerra tuvieran el carácter de "comisiones especiales" sino que, por el contrario, que se trata de órganos jurisdiccionales consagrados legalmente, que ejercen atribuciones propias de los tribunales de justicia en un escenario fáctico - jurídico procesal extraordinario que concita un procedimiento penal especial, propio del tiempo de guerra.

Actualmente este caso se encuentra en tramitación ante el $7^{\circ}$ Juzgado Civil de Santiago, en que Ernesto Galaz demandó al Fisco de Chile por la suma de \$300.000.000. ${ }^{127}$

\subsection{Algunas reflexiones sobre el razonamiento de la Corte Suprema en las resoluciones que acogen la solicitud de declaración previa}

El primer conjunto de datos relevantes consiste en el tipo de sistema en que se dicta la resolución impugnada, el tribunal que la dicta y el tipo de resolución que se impugna. De las cuatro solicitudes acogidas por la Corte Suprema, en dos se impugnan resoluciones dictadas en el sistema penal antiguo por Juzgados del Crimen de Santiago, específicamente, los autos de procesamiento y las sentencias definitivas condenatorias. ${ }^{128}$ Por otro lado, una resolución impugnada corresponde al sistema acusatorio actual, dictada por un Juez de Garantía y recae sobre medidas cautelares. ${ }^{129}$ Finalmente, una se refiere a las resoluciones condenatorias dictada en sede de justicia militar, por el Tribunal Militar en Tiempos de Guerra. $^{130}$

Con respecto al tipo de resolución que pone término al proceso, resulta que, de las cuatro resoluciones estudiadas en esta sección, dos terminaron por sentencia absolutoria dictada por la Corte Suprema luego de que acogiera un recurso de revisión. ${ }^{131}$ Por otro lado, una causa terminó con la sentencia absolutoria de segunda instancia dictada por la Corte de

\footnotetext{
${ }^{127}$ Causa C-34256-2017 del $7^{\circ}$ Juzgado Civil de Santiago.

${ }^{128}$ El Vigésimo Juzgado del Crimen de Santiago en el Caso María Yáñez, SCS rol nº5411-2010 y el 3º Juzgado del Crimen de Santiago en el Caso Mauricio Hernández, SCS rol nº25658-2014.

${ }^{129}$ La resolución que sometió al solicitante a prisión preventiva y la que le impuso la medida cautelar de arresto domiciliario nocturno del Juzgado de Garantías de Los Andes en el Caso General Chavarría (SCS rol $\left.\mathrm{n}^{\circ} 1579-2015\right)$.

${ }^{130}$ Caso Ernesto Galaz, SCS nº11486-2017.

${ }^{131}$ Casos María Yáñez (SCS rol n5411-2010) y Ernesto Galaz (SCS nº11486-2017).
} 
Apelaciones de Santiago luego de acoger la apelación deducida. ${ }^{132}$ Finalmente, un caso terminó con la sentencia absolutoria dictada por un Tribunal de Oral en lo Penal. ${ }^{133}$

Para ilustrar más claramente los datos descritos en los dos párrafos anteriores, incluimos a continuación una tabla resumen que permite comparar simultáneamente estos datos respecto de cada una de las causas.

Tabla n ${ }^{\circ}$ 11:

Resumen casos solicitudes acogidas por Corte Suprema, años 2006-2017

Fuente: Elaboración propia

\begin{tabular}{|c|c|c|c|c|}
\hline Caso & $\begin{array}{l}\text { María } \\
\text { Yáñez }\end{array}$ & $\begin{array}{l}\text { Mauricio } \\
\text { Hernández }\end{array}$ & $\begin{array}{c}\text { General } \\
\text { Chavarría }\end{array}$ & $\begin{array}{c}\text { Ernesto } \\
\text { Galaz }\end{array}$ \\
\hline Sistema & Antiguo & Antiguo & Acusatorio & $\begin{array}{l}\text { Justicia } \\
\text { Militar }\end{array}$ \\
\hline Tribunal & $\begin{array}{c}20^{\circ} \text { Juzgado } \\
\text { del Crimen de } \\
\text { Santiago }\end{array}$ & $\begin{array}{c}3^{\circ} \text { Juzgado del } \\
\text { Crimen de } \\
\text { Santiago }\end{array}$ & $\begin{array}{l}\text { Juzgado de } \\
\text { Garantías de } \\
\text { Los Andes }\end{array}$ & $\begin{array}{c}\text { Tribunal } \\
\text { Militar en } \\
\text { Tiempos de } \\
\text { Guerra }\end{array}$ \\
\hline $\begin{array}{l}\text { Resolución(es) } \\
\text { impugnada(s) }\end{array}$ & $\begin{array}{c}\text { Auto de } \\
\text { procesamiento } \\
\text { y condenatoria }\end{array}$ & $\begin{array}{c}\text { Auto de } \\
\text { procesamiento } \\
\text { y condenatoria }\end{array}$ & $\begin{array}{c}\text { Prisión } \\
\text { preventiva y } \\
\text { arresto } \\
\text { domiciliario } \\
\text { nocturno }\end{array}$ & Condenatoria \\
\hline $\begin{array}{c}\text { Resolución } \\
\text { que termina el } \\
\text { proceso }\end{array}$ & $\begin{array}{l}\text { Absolutoria en } \\
\text { proceso de } \\
\text { revisión }\end{array}$ & $\begin{array}{c}\text { Absolutoria de } \\
\text { segunda } \\
\text { instancia }\end{array}$ & $\begin{array}{c}\text { Absolutoria } \\
\text { primera } \\
\text { instancia } \\
\text { (TOP) }\end{array}$ & $\begin{array}{l}\text { Absolutoria } \\
\text { en proceso de } \\
\text { revisión }\end{array}$ \\
\hline $\begin{array}{l}\text { Tribunal que } \\
\text { dicta la } \\
\text { resolución } \\
\text { que termina el } \\
\text { proceso } \\
\end{array}$ & $\begin{array}{c}\text { Corte } \\
\text { Suprema }\end{array}$ & $\begin{array}{c}\text { Corte de } \\
\text { Apelaciones } \\
\text { de Santiago }\end{array}$ & $\begin{array}{l}\text { Tribunal Oral } \\
\text { en lo Penal }\end{array}$ & $\begin{array}{c}\text { Corte } \\
\text { Suprema }\end{array}$ \\
\hline $\begin{array}{c}\text { Proceso en } \\
\text { que se dicta la } \\
\text { resolución } \\
\text { que termina el } \\
\text { proceso } \\
\end{array}$ & $\begin{array}{l}\text { Recurso de } \\
\text { Revisión }\end{array}$ & Apelación & $\begin{array}{c}\text { Juicio Oral } \\
\text { Ordinario }\end{array}$ & $\begin{array}{l}\text { Recurso de } \\
\text { Revisión }\end{array}$ \\
\hline
\end{tabular}

A partir de estos datos pareciera que la Corte Suprema no tiene objeciones en cuanto al tipo de sistema en que se puede producir una resolución injustificadamente errónea. Como puede verse, no sólo reconoce resoluciones con este vicio en el sistema inquisitivo (que es el que se encontraba vigente cuando se crea esta norma) sino también en el sistema de justicia militar y sistema acusatorio. En este sentido, argumenta explícitamente que las resoluciones dictadas por el Tribunal Militar en Tiempos de Guerra y las resoluciones sobre

\footnotetext{
132 Caso Mauricio Hernández (SCS rol n²5658-2014).

${ }^{133}$ Caso General Chavarría (SCS rol nº1579-2015).
} 
medias cautelares dictadas por jueces de garantía pueden originar indemnización por error judicial. Por lo tanto, éste ítem no sería un obstáculo para obtener la indemnización.

La Corte, además, ha consolidado su criterio respecto a que no sólo procede la indemnización por error judicial tratándose de los autos de procesamiento y de las sentencias condenatorias, como dice expresamente la norma, sino también sobre las resoluciones que decretan medidas cautelares. Si bien la Corte ha afirmado desde el 2014 esta posibilidad como ya señalamos, la primera vez que declara una resolución de este tipo como injustificadamente errónea se produce en el caso de Leonardo General Chavarría de 2015.

Finalmente, un dato destacable es que, en dos de las cuatro resoluciones estudiadas, la Corte ya se había pronunciado en forma favorable al solicitante, concediendo un recurso de revisión en contra de la sentencia impugnada. Sin embargo, no podría afirmarse que la Corte falla en compromiso con su propia decisión previa o que es un factor que permite a las solicitudes tener éxito, puesto que los recursos de revisión acogidos son muchos más ${ }^{134}$ y, como puede apreciarse, sólo dos obtuvieron decisión favorable de la Corte Suprema por esta vía.

Pasando a otro tema, específicamente, a la descripción de la solicitud que hace la Corte en su resolución, parece que no es relevante, o al menos la Corte no lo registra en su sentencia, si el solicitante ofrece una definición de los conceptos de resolución "injustificadamente errónea" y resolución "arbitraria" o si dedica argumentos explicar por qué la resolución impugnada tendría estas características. Llegamos a esta conclusión porque en $\operatorname{dos}^{135}$ de las cuatro causas estudiadas simplemente se describen los hechos procesales del caso, mientras que en sólo una de ellas ${ }^{136}$ el solicitante describe, además, porqué la resolución que impugna es "injustificadamente errónea o arbitraria". Finalmente, sólo en una solicitud ${ }^{137}$ se ofrece tanto una descripción de los hechos, una definición de los conceptos indicados y una explicación de por qué la resolución impugnada tendría estas características, previamente definidas. De esta manera, sólo en esta última solicitud los argumentos del litigante podrían considerarse como "adecuados" al propósito de esta instancia que, recordemos, consiste en persuadir a la Corte de que se ha cometido un error judicial "injustificadamente erróneo o arbitrario" para que haga una declaración en ese sentido.

En cuanto al género de los solicitantes favorecidos por la Corte Suprema, sólo una de los cuatro solicitantes es mujer, es decir, 25\%. Ello representa un porcentaje levemente superior a la cantidad total de mujeres solicitantes en el período en estudio que, como se vio anteriormente, corresponde al 14,3\%. En este sentido, el género no parece ser un obstáculo o un factor determinante a la hora de obtener una sentencia favorable en esta materia. Con

\footnotetext{
${ }^{134}$ Como afirma DUCE, “Los recursos de revisión”, cit. nota nº 7, p. 12, en el período 2007-2016 se acogieron 48 recursos del sistema acusatorio, por lo que el número de recursos de revisión acogidos en el período que estudia este trabajo (2006-2017) incluyendo los del sistema acusatorio e inquisitivo, debe ser mucho mayor.

${ }^{135}$ Casos General Chavarría (SCS rol nº1579-2015) y Ernesto Galaz (SCS nº11486-2017).

${ }^{136}$ Caso María Yáñez (SCS rol n5411-2010).

${ }^{137}$ Caso Mauricio Hernández (SCS rol nº25658-2014).
} 


\section{Polít. Crim. Vol. 14, No 28 (Diciembre 2019), Art. 6, pp. 216-268. [http://politcrim.com/wp-content/uploads/2019/12/Vol14N28A6.pdf]}

respecto a los delitos imputados a los solicitantes de esta sección, no se aprecia ningún tipo de uniformidad o similitud. En este sentido, no parece ser relevante el tipo penal en juego.

En relación a los perjuicios sufridos por los solicitantes, resulta que es un factor común en los cuatro casos la presencia de alguna forma de privación de libertad. En efecto, en dos casos los solicitantes estuvieron detenidos por tres días, ${ }^{138}$ en uno el solicitante estuvo en prisión preventiva por tres meses y sujeto a arresto domiciliario nocturno por nueve meses, ${ }^{139}$ mientras que otro solicitante alega haber sido detenido e incluso torturado. ${ }^{140}$

Sobre las penas impuestas en las tres sentencias condenatorias que fueron declaradas injustificadamente erróneas, en una no hay información, ${ }^{141}$ en una se condena a una pena privativa de libertad (41 días de prisión grado máximo ${ }^{142}$ ) y en una el solicitante es condenado a muerte, pena que fue modificada a presidio perpetuo, la que a su vez fue sustituida por extrañamiento. ${ }^{143}$ De esta manera, en al menos dos de los tres casos en que la Corte declara una sentencia condenatoria "injustificadamente errónea", se trata de condenas privativas de libertad (prisión y presidio).

En cuando a la postura del Consejo de Defensa del Estado y del Fiscal Judicial en uno de ellos ambas instituciones se oponen a la solicitud tanto por motivos de forma como de fondo. ${ }^{144}$ En dos casos se oponen a la solicitud por motivos de fondo. ${ }^{145}$ Finalmente, en un caso el Consejo de Defensa se opone a la solicitud por motivos de forma y fondo y, en cambio, la Fiscal Judicial concuerda con la solicitud. ${ }^{146}$ En suma, parece ser que, en las resoluciones favorables a la solicitud, la opinión de estos intervinientes no resulta decisiva a la hora de determinar el éxito o fracaso de una solicitud, puesto que en tres de los cuatro casos en que intervienen, la Corte falla en total oposición a la opinión de éstos. Sin embargo, si observamos la totalidad de resoluciones podemos llegar a la conclusión contraria, puesto que de los 52 casos en que interviene el Consejo de Defensa del Estado, en todos se opone a la solicitud y, como hemos visto, sólo en estos cuatro casos la Corte falla en contra de sus pretensiones.

Como se pudo apreciar en la descripción detallada de los casos realizada anteriormente, todas las sentencias que acogen la solicitud en estudio, han declarado las resoluciones impugnadas como "injustificadamente erróneas", de modo que no se sabe aún, en qué casos la Corte considera que existe "arbitrariedad". Sin embargo, a partir de estas resoluciones podemos concluir en qué casos la Corte estima que una resolución es injustificadamente errónea o arbitraria. En primer lugar, se puede extraer del caso de María Yáñez que la Corte estimaría que una resolución es injustificadamente errónea cuando los jueces no toman las medidas mínimas para cerciorarse de la identidad del sujeto a quien se condena o respecto

\footnotetext{
${ }^{138}$ Caso María Yáñez (SCS rol n5411-2010) y caso Mauricio Hernández (SCS rol n²5658-2014).

${ }^{139}$ Caso General Chavarría (SCS rol nº1579-2015).

${ }^{140}$ Caso Ernesto Galaz (SCS nº11486-2017). La resolución no especifica el tiempo que estuvo detenido.

${ }^{141}$ Caso Mauricio Hernández (SCS rol n²5658-2014).

${ }^{142}$ Caso María Yáñez (SCS rol n5411-2010).

${ }^{143}$ Caso Ernesto Galaz (SCS nº11486-2017).

${ }^{144}$ Caso María Yáñez (SCS rol n5411-2010).

${ }^{145}$ Caso Mauricio Hernández (SCS rol nº25658-2014) y Caso General Chavarría (SCS rol nº1579-2015).

${ }^{146}$ Caso Ernesto Galaz (SCS nº11486-2017).
} 
de quien se toman decisiones a lo largo del proceso. En este sentido, los jueces no podrían simplemente confiar en lo que dice el Ministerio Público o el propio imputado respecto de su identidad, debiendo hacer uso de las herramientas que le proporciona el sistema para cotejar la identidad del sujeto, por ejemplo, obtener del Servicio de Registro Civil e Identificación el cotejo de sus huellas dactilares. ${ }^{147}$

En los casos de Mauricio Hernández y de Leonardo General Chavarría, la Corte estima que el error injustificado recae en la valoración de los antecedentes que, a su juicio, eran insuficientes para decretar la resolución en cuestión. Es menester notar que se trata de jueces de sistemas distintos; Juez del Crimen y Juez de Garantías, respectivamente, lo que demuestra, en principio, que la Corte Suprema no hace diferencias en el estándar de razonabilidad que deben cumplir al valorar los antecedentes del caso, de manera que ambos cometen un "error injustificado". En este sentido, un tribunal incurre en un error injustificado cuando no hay antecedentes, en absoluto, respecto de un elemento objetivo del tipo penal. En un caso, no había antecedentes que acreditaran el engaño de la supuesta estafa mientras que en el otro no había antecedentes que probaran la falta de consentimiento de la víctima en la supuesta violación.

Finalmente, con el caso Ernesto Galaz la Corte afirma que existe un error injustificado cuando el tribunal impone una condena basada únicamente en una confesión obtenida por vía de la tortura. Deja claro, además, que no es un impedimento para obtener la indemnización por error judicial, haber obtenido otro tipo de indemnizaciones o haber sido condenado por el Tribunal Militar en Tiempos de Guerra.

\section{Conclusiones}

Como señalamos en la introducción, el objetivo de este trabajo ha sido el contribuir al conocimiento del mecanismo de indemnización por error judicial contemplado en el artículo $19 \mathrm{n}^{\circ} 7$ letra i) de la Constitución por medio de un estudio de corte empírico del total de solicitudes presentadas a la Corte Suprema en el período comprendido entre los años 2006 a 2017. Hemos intentado determinar si el funcionamiento en la práctica de esta herramienta entrega una adecuada protección y cobertura para reparar a las personas que han sido objeto de condenas e imputaciones erróneas. Nuestra respuesta es que esta institución está todavía lejos de cumplir adecuadamente con las necesidades de reparación de las víctimas de los errores. En efecto, como ya intuía la doctrina previa, sólo un porcentaje menor de estas solicitudes (cuatro casos que representan $6,1 \%$ en el período estudiado) tiene una acogida favorable por la Corte Suprema.

Más allá de este dato, la investigación ha permitido identificar varias cuestiones que no habían sido abordadas por la literatura nacional disponible. Lo primero que llama poderosamente la atención es la baja cantidad de solicitudes que se presentan, las que llegan a un promedio de 6,4 anuales en el período en estudio y que darían cuenta de una

\footnotetext{
${ }^{147}$ Cabe hacer la prevención que este caso se refiere al sistema inquisitivo en donde la regulación legal le entregaba mayores responsabilidades de investigación al juez del crimen. En un caso reciente no incluido en esta investigación por haberse resuelto en un recurso de revisión la Corte parece extender el criterio del caso de María Yáñez a los jueces del sistema acusatorio. SCS rol n 44270-2017 (Caso Marcos Cofré).
} 


\section{Polít. Crim. Vol. 14, No 28 (Diciembre 2019), Art. 6, pp. 216-268. [http://politcrim.com/wp-content/uploads/2019/12/Vol14N28A6.pdf]}

cifra relativamente estabilizada desde el año 2001. Una primera explicación a este fenómeno sería el desincentivo que existe para las víctimas de estos errores de utilizar este mecanismo frente a la muy baja probabilidad de obtener la declaración previa que les permita luego demandar en sede civil. Nos parece que se trata de un argumento fuerte, pero que no agota el tema. ${ }^{148}$ Por lo mismo, es necesario también explorar otras razones que puedan complementar a esta primera explicación. En esta dirección, nos parece que la falta de representación legal gratuita proporcionada por el Estado en esta instancia podría ser un factor adicional relevante. En efecto, la Defensoría Penal Pública no tiene competencia para asumir la defensa de quien solicita la declaración ${ }^{149}$ y la Corporación de Asistencia Judicial tiene una cobertura limitada debido a que sólo ofrecen patrocinio a quienes cumplen varios requisitos de orden socio-económico. ${ }^{150}$ En consecuencia, parte de la explicación sobre la baja cantidad de solicitudes de declaración previa ante la Corte Suprema podría deberse también a barreras de acceso que habría que estudiar con más profundidad con el propósito de removerlas por medio de reformas legales o el diseño de políticas públicas.

Otro hallazgo interesante es que una vez presentada la solicitud, los obstáculos de admisibilidad no parecieran tener la relevancia que en otras materias que son de competencia de la Corte Suprema sí tienen (vgr. Recurso de Nulidad por causal del artículo 373 a del CPP y Recurso de Revisión). Como vimos, un porcentaje bajo de casos (menos del $20 \%$ ) es declarado inadmisible por razones de forma y al analizar esas resoluciones hemos descubierto se trata en su mayoría de situaciones claras de inadmisibilidad, por ejemplo, presentación extemporánea de la solicitud (siete de 13 solicitudes que representan el 53,8\% de las inadmisibilidades de forma). Si bien el plazo para interponer esta solicitud podría ser discutido ya que no es parte de nuestra regulación constitucional (sólo aparece como una exigencia del autoacordado de 1996), un cambio en esta materia, que en todo

\footnotetext{
${ }^{148}$ Por ejemplo, en materia de recurso de revisión la probabilidad que una solicitud sea acogida por la Corte Suprema es de aproximadamente un $8 \%$ (no muy superior a las de la declaración previa) e igualmente el flujo de solicitudes anuales es muy superior, llegando a un promedio de 60 anuales en el período entre 2007 y 2016. DUCE, “Los recursos de revisión”, cit. nota nº7, p. 12.

${ }^{149}$ Esta falta de competencia está dada por el artículo $2^{\circ}$ de la Ley 19.718 Que Crea la Defensoría Penal Pública, que señala: "La Defensoría tiene por finalidad proporcionar defensa penal a los imputados o acusados por un crimen, simple delito o falta que sea de competencia de un juzgado de garantía o de un tribunal de juicio oral en lo penal y de las respectivas Cortes, en su caso, y que carezcan de abogado". Como puede observarse, el artículo limita el patrocinio de la Defensoría a quienes tienen calidad de "imputados" o "acusados", mientras que el artículo $7^{\circ}$ del Código Procesal Penal define como "imputado" a "la persona a quien se atribuyere participación en un hecho punible desde la primera actuación del procedimiento dirigido en su contra y hasta la completa ejecución de la sentencia." En suma, quien ha sido procesado o condenado y luego absuelto o favorecido por el sobreseimiento definitivo (el titular de la indemnización por error judicial según el art. 19 n7 letra i) CPR) no es "imputado" ni "acusado", por lo que la Defensoría no puede asumir su representación. Por esta razón, la Defensoría Penal Pública suscribió un convenio con la Fundación Probono, para que los abogados de esta última puedan asumir gratuitamente la representación legal de personas inocentes que fueron injustamente acusadas de cometer delitos. La renovación de dicho convenio fue anunciada por la Defensoría en su página web http://www.dpp.cl/sala_prensa/noticias detalle/8369/defensoria-y-fundacion-pro-bono-renuevan-convenioque-beneficia-a-inocentes-injustamente-acusados (visitado el 18.1.2019).

${ }^{150}$ Según el artículo $2^{\circ}$ de la Ley $\mathrm{N}^{\mathrm{o}} 17.995$ que crea las Corporaciones de Asistencia Judicial, su "finalidad será prestar asistencia jurídica y judicial gratuita a personas de escasos recursos”. En la página web http://www.cajmetro.cl/quien-puede-ser-nuestro-usuario/ (visitado el 18.1.2019) aparecen los requisitos para ser usuario del servicio.
} 
caso pensamos se debe estudiar, parece que no tendría un efecto significativo en la cantidad de solicitudes tramitadas en el fondo ni en el porcentaje de las mismas aprobadas.

En este contexto, el principal problema que explica el bajo porcentaje de solicitudes aprobadas está vinculado a los estándares exigidos por la Constitución para dar lugar a la declaración previa por parte de la Corte Suprema, tal como ya venía señalando la doctrina y daban cuenta los proyectos de reforma constitucional presentados en la materia en los últimos años. La jurisprudencia del período muestra como la interpretación de lo que constituye una resolución "injustificadamente errónea o arbitraria" sigue siendo muy estricta. Pero más allá de eso, la investigación ha permitido detectar que en su aplicación a los casos concretos se presentan algunos defectos argumentativos importantes de parte de la Corte Suprema al confundir el alcance de ambos o al no explicitar con claridad las razones que justifican de manera específica cómo se da alguno de ellos en los hechos del caso. Con todo, otro hallazgo relevante de la investigación es que este fenómeno no sería sólo achacable a la Corte, sino que en parte sería consecuencia del mal trabajo de los litigantes. Como se recordará, pudimos identificar serios problemas derivados de la falta de precisión de los solicitantes al pedir la declaración previa al error judicial. En sólo un $13 \%$ de los casos que obtuvimos información sobre este punto se especifican cuál de los dos "vicios" posibles adolece la resolución que impugnan. En su gran mayoría, en cambio, los solicitantes se limitan a repetir la fórmula "injustificadamente errónea o arbitraria" que utiliza textualmente la norma constitucional o, incluso, atribuir ambos vicios conjunta o alternativamente.

En definitiva, pensamos que los hallazgos de esta investigación dan sustento con base empírica a la necesidad de realizar una revisión profunda tanto de nuestra actual regulación constitucional como del autoacordado que la implementa. Las regulaciones y prácticas actuales no parecen establecer un equilibrio adecuado entre los legítimos intereses del Estado de no afectar la posibilidad de tener persecuciones penales vigorosas (protegiendo de paso las arcas fiscales) y, por otra parte, reparar a quienes sufren daños graves como consecuencia de errores judiciales. Con todo, nos parece que los cambios debieran ser objeto de reflexión profunda y de investigaciones complementarias a la presente, por ejemplo de derecho comparado, que permitan establecer un modelo de reparación de errores judiciales que -más allá de las buenas intenciones- tenga posibilidades de ciertas de funcionar adecuadamente. ${ }^{151}$

\footnotetext{
${ }^{151}$ Por ejemplo, la doctrina desde hace mucho tiempo ha sugerido eliminar la palabra "injustificadamente" de la norma constitucional (CALDERA, "Interpretación”, cit. nota n¹2, p. 363; ZÚÑIGA, "La Acción”, cit. nota $\mathrm{n}^{\circ} 19$, p. 39) como una solución de reforma posible. Nos parece que dicha propuesta es interesante, pero requeriría una mirada más compleja y completa de la regulación para tener un efecto relevante e instalar un sistema compensatorio equilibrado.
} 


\section{Bibliografía}

BALLIVIAN, Pedro, "Responsabilidad del Estado por conductas injustificadamente erróneas o arbitrarias del Ministerio Público: análisis comparativo y jurisprudencial", Revista Ius et Praxis, Año 19, N 2 (2013), pp. 53-84.

BARROS, Enrique, Tratado de responsabilidad extracontractual, Santiago: Editorial Jurídica de Chile, 2006.

CALDERA, Hugo, "Interpretación que la Corte Suprema ha dado a la norma constitucional sobre indemnización del error judicial", Revista de Derecho Público, n³7-38 (1985), pp. 335-364.

CAMPBELL, Katryn, DENOV, Myriam, "The burden of innocence: coping with a wrongful imprisonment", Canadian Journal of Criminal Law and Criminal Justice, $\mathrm{n}^{\circ} 46$ (2004), pp. 139-163.

CARMONA, Carlos, "La responsabilidad del Estado-juez: Revisión y proyecciones", Revista de Derecho Público, vol. 66 (2004), pp. 307-357.

CAROCCA, Alex, "Reflexiones sobre el derecho a la reparación del error judicial en Chile a propósito de la solución amistosa ante la comisión Interamericana de Derechos Humanos en el llamado caso del puente La Calchona", Revista Ius Et Praxis, Vol. 8, $\mathrm{n}^{\mathrm{o}} 2$ (2002), pp. 641-660.

CASTILlO, Ignacio, "Enjuiciando al Proceso Penal Chileno desde el Inocentrismo (algunos apuntes sobre la necesidad de tomarse en serio a los inocentes)", Revista Política Criminal, Vol. 8, no 15 (2013), pp. 249-313.

CENTRO DE ESTUDIOS DE LA JUSTICIA, El recurso de nulidad en materia penal: jurisprudencia de la Corte Suprema años 2001-2013, Santiago: Facultad de Derecho Universidad de Chile, 2015.

CORDERO, Luis, “¿En qué estamos con la responsabilidad por error judicial?”, El Mercurio Legal, 25 de junio de 2014, en: http://www.elmercurio.com/Legal/Noticias/Analisis-Juridico/2014/06/25/En-queestamos-con-la-responsabilidad-por-error-judicial.aspx [visitado el 18.01.2019]

CORDERO, Eduardo, "La ampliación de responsabilidad del Estado juez a propósito de las sentencias de la Corte Suprema en materia de medidas cautelares privativas de libertad y los errores judiciales fuera del ámbito penal”, en: VAN WEEZEL, Alex, et. al, Sentencias destacadas 2015, Santiago: Ediciones Libertad y Desarrollo, 2016, pp. 15-35.

DÍAZ, Nataly; MUÑOZ, Pamela, "La responsabilidad del Estado-Juez: Buenas razones para proponer una acepción amplia de error judicial en Chile", Revista de Derecho Público, vol. 83, $2^{\circ}$ semestre (2015), pp. 37-60.

DIRECCIÓN DE ESTUDIOS DE LA CORTE SUPREMA, Peritajes en Chile, Santiago: Corte Suprema, 2017, 47 pp.

DUCE, Mauricio, "La indemnización por error judicial y las medidas cautelares personales: la consolidación de una nueva doctrina de parte de la Corte Suprema", El Mercurio Legal, 4 de diciembre de 2015, en: http://www.elmercurio.com/Legal/Noticias/Analisis-Juridico/2015/12/04/Laindemnizacion-por-error-judicial-y-las-medidas-cautelares-personales-laconsolidacion-de-una-nueva-doctrina-de-parte-de-la-Corte-Suprema.aspx [visitado el 18.01.2019] 
DUCE, Mauricio; VILLARROEL, Romina, "Indemnización por error judicial: una aproximación empírica a la jurisprudencia de la Corte Suprema de los años 2006-2017”

DUCE, Mauricio, "Los recursos de revisión y la condena de inocentes en Chile: una aproximación empírica en el periodo 2007-2016", en Doctrina y jurisprudencia penal: Recursos de amparo y revisión, n³0 (2017), pp. 3-40.

DUCE, Mauricio, "Los reconocimientos oculares: una aproximación empírica a su funcionamiento y algunas recomendaciones para su mejora", Polit. crim. Vol. 12, No 23 (2017), Art. 9, pp. 291-379.

DUCE, Mauricio, "Presos sin condena ni reparación”, El Mercurio Legal, 22 de septiembre de 2017, en: http://www.elmercurio.com/Legal/Noticias/AnalisisJuridico/2017/09/22/Presos-sin-condena-ni-reparacion.aspx [visitado el 05.01.2019]

DUCE, Mauricio, “Una aproximación empírica al uso y prácticas de la prueba pericial en el proceso penal Chileno a la luz de su impacto en los errores del sistema", Polít. crim. Vol. 13, No 25 (2018), Art. 2, pp. 42-103.

EVANS, Enrique, Los derechos constitucionales, $t$. II, Santiago: Editorial Jurídica de Chile, 1986.

FERNÁNDEZ, Miguel Ángel, La nueva justica penal frente a la constitución, Santiago: Lexis Nexis, 2006.

FORST, Brian, Wrongful Conviction and Miscarriages of Justice, Causes and Remedies in North American and European Criminal Justice Systems: Wrongful Convictions in a World of Miscarriages of Justice, New York: Routledge, 2013, pp. 15-43.

GARRIDO, Mario, "La Indemnización por Error Judicial en Chile", Revista Ius et Praxis, año 5, no1 (1999), pp. 473-482.

GARRET, Brandon, Convicting the Innocent: Where Criminal Prosecutions Go Wrong, Estados Unidos: Harvard University Press, 2011.

GONZÁlEZ-WILHELM, Leonardo, Prueba pericial, litigación con peritos y medicina legal, Santiago: Thomson Reuters, 2018.

GROSS, Samuel, et al, "Rate of false convictions of criminal defendants who are sentenced to death", Proceedings of the National Academy of Sciences of the United States of America, vol. 11, n 20 (2014), pp.7230-725.

GROUNDS, Adrian, "Psychological consequences of wrongful convictions and imprisonment", Canadian Journal of Criminal Law and Criminal Justice, $\mathrm{n}^{\circ} 46$ (2004), pp. 165-182.

GOULD, Jon, et al, "Predicting Erroneous Convictions", Iowa Law Review, vol. 99, 2014, pp. 471-522.

HERNÁNDEZ, Domingo, "Error judicial: ensayo de interpretación constitucional”, Revista Ius et Praxis, año 5, no 1 (1999), pp. 473-482.

INSTITUTO NACIONAL DE DERECHOS HUMANOS, Informe anual 2014: situación de los derechos humanos en Chile, Santiago: Instituto Nacional de Derechos Humanos, 2015, 345 pp.

PRECHT, Jorge, "Resolución injustificadamente errónea o arbitraria en la indemnización por error judicial", Revista Estudios Constitucionales, año 2, nº1 (2004), pp. 175180.

RISINGER, Michael "Innocent convicted: an empirically justified wrongful conviction rate", The Journal of Criminal Law and Criminology, vol. 97, n 3 (2007), pp. 761806.

RONDINI, Patricio, La responsabilidad patrimonial del Estado juez en Chile, Santiago: Lexis Nexis, 2008. 


\section{Polít. Crim. Vol. 14, No 28 (Diciembre 2019), Art. 6, pp. 216-268. [http://politcrim.com/wp-content/uploads/2019/12/Vol14N28A6.pdf]}

RUIZ, Guillermo, "Apuntes acerca del injusto procesamiento", Revista de Derecho del Consejo de Defensa del Estado, n¹0 (2003), pp. 45-55.

SALAS, Jaime, Abono de la prisión preventiva en causa diversa, Santiago: Librotecnia, 2017.

SCOTT, Leslie, "It never ends: the psychological impact of wrongful convictions", American University Criminal Law Brief, vol. 5, n 2 (2010), art. 2, pp. 9-22.

SIMON, Dan, In Doubt: The Psychology of the Criminal Justice Process, Estados Unidos: Harvard University Press, 2012.

SOTO, Eduardo, "Responsabilidad del Estado por la actividad jurisdiccional", Revista Chilena de Derecho, Vol. 10, n $^{\circ} 1$ (1983), pp. 45-58.

SOTO, Pablo, "Responsabilidad patrimonial del Estado por funcionamiento anormal de la justicia (Corte Suprema)", Revista de Derecho, Vol. XXIX, n 1 (2016), pp. 331335.

VODANOVIC, Natalio, "Aspectos de las indemnizaciones por error judicial y por conductas erróneas del ministerio público, con el nuevo sistema procesal penal", Revista de Derecho del Consejo de Defensa del Estado, n¹3 (2005), pp. 83-87.

ZÚÑIGA, Francisco, "La Acción de indemnización por error judicial. Reforma constitucional. regulación infraconstitucional y jurisprudencia", Estudios Constitucionales, año 6, n² (2008), pp. 15-41. 
DUCE, Mauricio; VILLARROEL, Romina, "Indemnización por error judicial: una aproximación empírica a la jurisprudencia de la Corte Suprema de los años 2006-2017”

\section{Anexo}

\begin{tabular}{|c|c|c|c|c|c|c|c|}
\hline \multicolumn{6}{|l|}{ Listado completo de causas señaladas por la Dirección de Estudios de la Corte Suprema y } \\
\multicolumn{2}{|c|}{} \\
\hline Año & Rol & Año & Rol & Año & Rol & Año & Rol \\
\hline $\mathbf{2 0 0 6}$ & 151 & $\mathbf{2 0 0 8}$ & 4357 & $\mathbf{2 0 1 2}$ & 1998 & $\mathbf{2 0 1 4}$ & 32208 \\
\hline $\mathbf{2 0 0 6}$ & 350 & $\mathbf{2 0 0 8}$ & 5270 & $\mathbf{2 0 1 2}$ & 3170 & $\mathbf{2 0 1 4}$ & 32213 \\
\hline $\mathbf{2 0 0 6}$ & 351 & $\mathbf{2 0 0 8}$ & 7854 & $\mathbf{2 0 1 2}$ & 7279 & $\mathbf{2 0 1 5}$ & 1579 \\
\hline $\mathbf{2 0 0 6}$ & 2344 & $\mathbf{2 0 0 9}$ & 1678 & $\mathbf{2 0 1 2}$ & 7937 & $\mathbf{2 0 1 5}$ & 3075 \\
\hline $\mathbf{2 0 0 6}$ & 2457 & $\mathbf{2 0 0 9}$ & 5701 & $\mathbf{2 0 1 2}$ & 7939 & $\mathbf{2 0 1 5}$ & 9559 \\
\hline $\mathbf{2 0 0 6}$ & 3481 & $\mathbf{2 0 0 9}$ & 5742 & $\mathbf{2 0 1 2}$ & 7945 & $\mathbf{2 0 1 5}$ & 22900 \\
\hline $\mathbf{2 0 0 6}$ & 3815 & $\mathbf{2 0 1 0}$ & 398 & $\mathbf{2 0 1 2}$ & 8050 & $\mathbf{2 0 1 6}$ & 44998 \\
\hline $\mathbf{2 0 0 6}$ & 4815 & $\mathbf{2 0 1 0}$ & 2709 & $\mathbf{2 0 1 3}$ & 587 & $\mathbf{2 0 1 6}$ & 47665 \\
\hline $\mathbf{2 0 0 6}$ & 5612 & $\mathbf{2 0 1 0}$ & 2751 & $\mathbf{2 0 1 3}$ & 7478 & $\mathbf{2 0 1 6}$ & 70829 \\
\hline $\mathbf{2 0 0 6}$ & 5796 & $\mathbf{2 0 1 0}$ & 2804 & $\mathbf{2 0 1 3}$ & 9120 & $\mathbf{2 0 1 6}$ & 92766 \\
\hline $\mathbf{2 0 0 6}$ & 5938 & $\mathbf{2 0 1 0}$ & 4463 & $\mathbf{2 0 1 3}$ & 14142 & $\mathbf{2 0 1 6}$ & 92767 \\
\hline $\mathbf{2 0 0 7}$ & 408 & $\mathbf{2 0 1 0}$ & 5411 & $\mathbf{2 0 1 3}$ & 16346 & $\mathbf{2 0 1 6}$ & 92769 \\
\hline $\mathbf{2 0 0 7}$ & 3030 & $\mathbf{2 0 1 0}$ & 7720 & $\mathbf{2 0 1 4}$ & 4921 & $\mathbf{2 0 1 6}$ & 83373 \\
\hline $\mathbf{2 0 0 7}$ & 5572 & $\mathbf{2 0 1 0}$ & 7837 & $\mathbf{2 0 1 4}$ & 7666 & $\mathbf{2 0 1 7}$ & 9316 \\
\hline $\mathbf{2 0 0 7}$ & 6190 & $\mathbf{2 0 1 0}$ & 8462 & $\mathbf{2 0 1 4}$ & 9568 & $\mathbf{2 0 1 7}$ & 19263 \\
\hline $\mathbf{2 0 0 8}$ & 498 & $\mathbf{2 0 1 1}$ & 1465 & $\mathbf{2 0 1 4}$ & 11730 & $\mathbf{2 0 1 7}$ & 33813 \\
\hline $\mathbf{2 0 0 8}$ & 1386 & $\mathbf{2 0 1 1}$ & 5269 & $\mathbf{2 0 1 4}$ & 16631 & $\mathbf{2 0 1 7}$ & 11486 \\
\hline $\mathbf{2 0 0 8}$ & 2120 & $\mathbf{2 0 1 1}$ & 9957 & $\mathbf{2 0 1 4}$ & 22356 & & \\
\hline $\mathbf{2 0 0 8}$ & 2640 & $\mathbf{2 0 1 1}$ & 12725 & $\mathbf{2 0 1 4}$ & 22498 & & \\
\hline $\mathbf{2 0 0 8}$ & 3450 & $\mathbf{2 0 1 2}$ & 1238 & $\mathbf{2 0 1 4}$ & 25658 & & \\
\hline
\end{tabular}

